\title{
Reaching for Yield in the Bond Market
}

\section{Citation}

Becker, Bo, and Victoria Ivashina. "Reaching for Yield in the Bond Market." Journal of Finance 70, no. 5 (October 2015): 1863-1902.

\section{Permanent link}

http://nrs.harvard.edu/urn-3:HUL.InstRepos:11337406

\section{Terms of Use}

This article was downloaded from Harvard University's DASH repository, and is made available under the terms and conditions applicable to Open Access Policy Articles, as set forth at http:// nrs.harvard.edu/urn-3:HUL.InstRepos:dash.current.terms-of-use\#OAP

\section{Share Your Story}

The Harvard community has made this article openly available.

Please share how this access benefits you. Submit a story.

Accessibility 

H A R A R D
B U S I N E S
S C HOO L

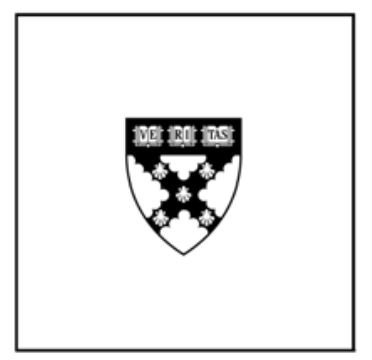

\title{
Reaching for Yield in the Bond Market
}

\author{
Bo Becker \\ Victoria Ivashina
}

\section{Working Paper}

12-103

March 12, 2013 


\title{
REACHING FOR YIELD IN THE BOND MARKET
}

\author{
Bo Becker \\ Harvard University and NBER \\ Victoria Ivashina \\ Harvard University and NBER
}

First version: May, 2012

This version: December, 2012

\begin{abstract}
Reaching-for-yield-investors' propensity to buy riskier assets in order to achieve higher yields-is believed to be an important factor contributing to the credit cycle. This paper presents a detailed study of this phenomenon in the corporate bond market. We show that insurance companies, the largest institutional holders of corporate bonds, reach for yield in choosing their investments. Consistent with lower rated bonds bearing higher capital requirement, insurance firms' prefer to hold higher rated bonds. However, conditional on credit ratings, insurance portfolios are systematically biased toward higher yield, higher CDS bonds. Reaching-for-yield exists both in the primary and the secondary market, and is robust to a series of bond and issuer controls, including bond liquidity and duration, and issuer fixed effects. This behavior is related to the business cycle, being most pronounced during economic expansions. It is also more pronounced for firms with poor corporate governance and for which regulatory capital requirement is more binding. A comparison of the ex-post performance of bonds acquired by insurance companies shows no outperformance, but higher systematic risk and volatility.
\end{abstract}

Key words: Fixed income; Reaching for yield; Financial intermediation; Financial crises JEL Codes: G11, G22, G30

We appreciate comments and suggestions from Jack Bao, Jeff Brown, Jess Cornaggia, Ken Froot, Marcin Kacpercszyk, Chay Ornthanalai, Matti Peltonen, George Pennacchi, Andrei Shleifer, Jeremy Stein, Rene Stulz, Marti Subrahmanyam, Erik Stafford, Robert Stambaugh, participants at the NBER Summer Institute, and seminar participants at the Harvard Business School, Kansas City Federal Reserve, Michigan, Dartmouth, Ohio State University, New York University, Bergen, Toronto and Miami. We are grateful to Matt Kurzweil and Keith Osinski from TIAA-CREF and Matti Peltonen at New York State Department of Financial Services for helping us understand insurance companies' capital regulation. We also thank Chris Allen, Lydia Petersen, Jennifer Rhee and Baker Library Research Services for assistance with data. 
A key principle of finance is that in equilibrium there is a positive relation between the risk of an asset and its expected return. Comparisons of returns, therefore, are only meaningful on a risk-adjusted basis. But risk cannot be measured perfectly. This creates an important limitation in the delegation of investment decisions. Financial intermediaries and investment managers that are evaluated based on imperfect risk metrics face an incentive to buy assets that comply with a set benchmark but are risky on other dimensions; in other words, they have an incentive to "reach for yield". ${ }^{1}$ This could lead to excess risk taking in financial institutions, a persistent distortion of investments and, potentially, amplification of the overall risk in the economy. Indeed, reaching-for-yield is believed to be one of the core factors contributing to the buildup of credit that preceded the recent financial crisis (Yellen, 2011 and Rajan, 2010). ${ }^{2}$ Yet there is lack of clear empirical evidence on this phenomenon. This paper provides an economically important example of reaching-for-yield and connects it to investment decisions and incentives.

Reaching-for-yield is a broad phenomenon that is not limited to any specific asset class, but it is likely be more pronounced for illiquid and complex securities for which risk measurement is particularly problematic. In this paper, we study reaching-for-yield in the context of corporate bonds. The risk of corporate bonds and fixed income more generally is often assessed using credit ratings. The advantage of credit ratings as a risk measure is that-due to standardized and well-established scales - they are comprehensible and have broad coverage for many fixed income securities. Ratings are also not affected by liquidity or market conditions. Not surprisingly, ratings are commonly used for contracting and regulation purposes. However, ratings tend to be updated slowly (Cornaggia and Cornaggia, 2011) and depend on accuracy of rating methodology and absence of agency conflicts (Becker and Milbourn,

\footnotetext{
${ }^{1}$ Cox (1967) used the term “reaching for yield” to describe banks' tendency to lend to high risk borrowers as a way of increasing the promised yield. In this paper, we use this term in a broader sense to describe investors' preference for assets with higher returns.

${ }^{2}$ Rajan (2010) refers to this phenomenon as “searching for alpha”.
} 
2011). ${ }^{3}$ Given the discrepancy between credit ratings and market perception of risk, reaching-for yield by fixed income investors evaluated and/or regulated based on credit ratings should show up conditional on such risk benchmark.

We focus on insurance companies, the largest institutional holder of corporate and foreign bonds. According to the U.S. Flow of Funds Accounts, in 2010, their holdings represented \$2.3 trillion, or more than bond holdings of mutual and pension funds taken together. ${ }^{4}$ Regulation requires insurance companies to maintain minimum levels of capital on a risk-adjusted basis, often called "RBC" or risk-based capital. (On average, 91\% of all securities holdings by insurance companies are in fixed income (Nissim, 2010) making the treatment of fixed income the core component of the RBC calculation.) To determine the capital requirement for credit risk, corporate bonds are sorted into six broad categories (National Association of Insurance Commissioners, "NAIC”, risk categories 1 through 6) based on their credit ratings, with higher categories subject to higher capital requirement.

To test for reaching-for-yield we need a clear risk benchmark. Due to the portfolio composition, the type of regulation and the presence of government guarantees, the insurance industry presents an important and clear setting for studying reaching-for-yield. The central hypothesis is that insurance companies may attempt to increase the yield in their bond portfolio through taking on extra priced risk, while leaving capital requirements unaffected. To test this prediction, we examine promised yields and market perceptions of credit risk (as measured by spreads on credit default swaps, CDS) of insurance companies’ investments, conditional on NAIC risk categories. The holding data for the analysis comes from Lipper eMAXX and covers the 2004:Q1-2010:Q3 period, which we divide it into before and after the financial crisis. The data has a comprehensive coverage of quarterly fixed income holdings by individual insurance companies, mutual funds and pension funds.

\footnotetext{
${ }^{3}$ In particular, several issues have been raised about rating of structured products (e.g., Benmelech and Dlugosz, 2009).

${ }^{4}$ Investment decisions of insurance companies are also important because, like banks, insurance companies have liabilities to a broad population base.
} 
Our basic finding for the pre-crisis period is illustrated in Figure 1. In this figure, insurance firms’ investment behavior is benchmarked against other investors in our sample. Whereas insurance companies face capital requirements imposed by regulators based on credit ratings, this is not the case for mutual and pension funds. ${ }^{5}$ (This is not to say that mutual and pension funds do not reach for yield, but reaching behavior for these institutions would be driven by factors other than credit ratings and, therefore, would manifest itself differently.) Figure 1, Panel A shows that, consistent with risk-weighted capital requirement, insurance companies exhibit a strong preference for safer bonds. However, just the opposite is true within regulatory risk categories (Figure 1, Panel B). For securities rated AAA, AA, A or BBB (NAIC risk category 1 and 2) insurance companies hold 63\% of all bonds held by insurance companies, pension or mutual funds in the lowest yield quartile, but $86 \%$ in the highest yield quartile. The result is very similar for CDSs. ${ }^{6}$

\section{[FIGURE 1]}

This basic finding is robust to controlling for a set of bond and issuer characteristics, including duration, issue size, year of issuance, bond liquidity, and detailed credit rating, so it is unlikely to be driven by investor preferences over these characteristics. ${ }^{7}$ Also, while Figure 1 looks at the investment decisions at issuance; we find similar results using secondary market trading. The secondary market setting enables us to focus only on insurance firms and control for issuer-times-quarter fixed effect, ruling

\footnotetext{
${ }^{5}$ Although mutual funds and pension funds might explicitly commit to invest all or part of their portfolio in investment grade (Chernenko and Sunderam, 2012), they are not evaluated by its investors solely on its compliance with the specified mandate. For example, as any funds, fixed income funds available through Fidelity or Vanguard offer detailed information on fund risk, including historical standard deviation and market beta. On the other hand, even basic statistics like risk adjusted capital of insurance firms are not easily available to the general public, reinforcing risk-assessment set by regulators.

${ }^{6}$ An advantage of using CDS spreads in addition to yields is that they may be affected by illiquidity in a different way than positive net supply assets like bonds (Bongaerts, De Jong and Driessen 2011).

${ }^{7}$ As Longstaff, Mithal and Neis (2007) suggest, most of the variation in yields across corporate bonds is related to credit risk. Thus, it appears unlikely that insurance companies' high yields are a reflection of liquidity alone. This prior based on the bond pricing literature is confirmed in our tests of holdings at issuance: liquidity plays a limited role in bond selection.
} 
out differences in institutional preferences and bond cross-sectional differences as explanations of our results.

As a contributing factor to credit cycles, reaching-for-yield is believed to be pro-cyclical. There are several reasons why reaching may be less attractive during a downturn. First, downgrade probabilities rise during economic recessions, so the ratings of some high risk bonds may be less stable. Reaching-foryield could also be curtailed because of increased scrutiny of investment managers (Gennaioli, Shleifer and Vishny, 2012), or because lower quality managers become unwilling to take risks they do not understand (Gurrieri and Kondor, 2012). Finally, a shift in the riskiness of the environment, or a shift in interest-rate regime can make reaching-for-yield less attractive. We test and confirm predictions about cyclicality in reaching for yield behavior. Insurance companies’ propensity to pick high yield, high CDS bonds within given NAIC risk category disappears in the second half of 2007 and comes back in the second half of $2009 .^{8}$

There might be a concern that the documented investment pattern reflects insurance companies’ superior investment ability or access to investment opportunities, i.e., that what seems to be reaching-foryield is simply "alpha”. Note that such an alternative explanation is not trivial as it would need to account for the fact that reaching-for-yield is specific only to investment grade bonds and only to the period of credit expansion. Regardless, we directly assess insurance investors' ability to generate alpha by examining bond portfolio returns. Consistent with our conclusions, we find that bonds preferred by the insurance companies have lower returns (although significantly so only in some specifications), higher volatility in and higher exposure to market returns (beta). This confirms that insurance firms get higher yields by assuming risk. ${ }^{9}$

\footnotetext{
${ }^{8}$ This pattern echoes the changed risk appetite in money market mutual funds at the time, documented by Kacperczyk and Schnabl (2012).

${ }^{9}$ We also show that CDS spread is a good predictor of ratings downgrades: within NAIC1, the lowest CDS quartile has a $1 \%$ probability of a downgrade over the next quarter, but for the highest CDS quartile this probability is $6 \%$.We define downgrade as a change in rating that moves an issuer from one NAIC to any lower NAIC. The
} 
Why do investors reach for yield? There are several possible explanations. Capital requirements that reflect default risk but not covariances (Iannotta and Pennacchi, 2012), or imperfectly observable skill (Gurrieri and Kondor, 2012), can generate an incentive to acquire assets with high systemic risk. Rajan (2010) points to the presence of incentives for financial intermediaries to give an appearance of superior performance that leads them to take on tail risk (e.g., earthquake insurance) in times when financing is plentiful. Investment incentives at the insurance firms-discussed in more detail in the next section-are largely consistent with the framework outlines by Rajan (2010); in particular, in absence of default, performance is evaluated based on promised yields. Government guarantees for insurance firms may also generate risk shifting incentives (Jensen and Meckling, 1976). ${ }^{10}$ These are not mutually exclusive channels, and they share the common element that investment managers face different incentives than owners or regulators, leading to reaching-for-yield.

An alternative set of explanations implies that reaching-for-yield is a reflection of the preference for higher expected returns associated with riskier assets and a desire to offset constraints imposed by regulation (often referred to as "regulatory arbitrage"). ${ }^{11}$ Private contracting frictions like leverage constraints (Frazzini and Pedersen, 2011) could explain ultimate investors’ preference for riskier assets. In this setting, there is no conflict with an intermediary who is merely implementing the preferences of their investors. There had been some evidence of reaching-for-yield by banks, money market fund, structured products, and mutual funds; in all of these cases the reaching-for-yield seems to be triggered due to the agency frictions. Similarly, roughly $70 \%$ percent of the insurance companies' balance sheet is insurance policies (the fundamental reason for industries regulation); furthermore, these obligations are government guaranteed. It is unclear how reaching-for-yield by insurance firms shown in this paper could

overall frequencies are comparable to what rating agencies provide for historical transition densities (e.g. Moody's Investor Service 2002).

${ }^{10}$ Acharya and Richardson (2009) describe such guarantee-driven risk-shifting in banks.

${ }^{11}$ This is similar to Peltzman’s (1975) "belted-milquetoast-turned-daredevil” effect. 
be a reflection of insurance-policy holders' preferences. Nevertheless, to shed more light on the drivers behind reaching-for-yield behavior we look at the cross-section of insurance firms.

Consistent with risk-shifting, we find that insurance firms for which the capital constraint is more binding tend to reach for yield more. Controlling for regulatory capital constraints, publicly listed firms do not appear to reach for yield more than privately held companies. This suggests that earnings management or short-run performance pressure-which would appear more important to managers of public firms - is unlikely to motivate the observed investment behavior of companies that reach-for-yield. However, among public firms, those with better corporate governance show less evidence of reachingfor-yield. Although these findings are based on data for relatively few firms, it provides support in favor of a role for agency frictions.

In the final set of results we evaluate welfare consequences of reaching-for-yield. We look at two channels through which reaching-for-yield could have broader implication for the economy: concentration of systemic risk in the insurance firms' portfolios, the potential effect on the allocation of credit supply. First, we examine insurance companies' stock returns during the 2008. As documented by Koijen and Yogo (2012), insurance companies overall had been adversely affected during the crisis. Consistent with reaching for yield being associated with higher risk taking, we find bigger losses of equity value for those firms that had reached for yield more in their portfolio.

To assess the impact of insurance companies investment preferences on credit allocation, we compare the issuance of different investment grade bond issuers: those with high CDS spreads (whose bonds are favored by insurance companies) and those with low CDS spreads. We track bond issuance volumes by these two groups over time, and find that times with high issuance by riskier issuers coincides with times of pronounced reaching for yield by insurance firms. This evidence suggests an impact of insurance companies’ investment behavior on credit issuance volumes and quality.

Broadly speaking, our paper is related to the large literature on agency problems in delegated investment management, such as Chevalier and Ellison (1999) and to the literature on regulatory design (see Pigou (1938) and Laffont and Tirole 1993). However, our focus is on reaching-for-yield. In the 
context of securitization, several studies have shown evidence of agency-related problems that are consistent with reaching-for-yield among investment managers. For example, Keys et al. (2010) show that securitization reduces incentives of financial intermediaries to screen borrowers above and beyond a specific benchmark. Lax screening may produce the type of high-risk good-rating assets that comply with requirements for investors. Indeed, Coval, Jurek and Stafford (2009) show that leading to 2008 senior collateralized debt obligation (CDO) tranches appeared to misprice the systematic risk exposures. This finding is indicative of investors focusing exclusively on credit ratings, but it focuses on the supply side. Our paper provides an explanation for why there might be a demand for such assets. Another difference is that we examine corporate bond markets, by far the largest category of non-government fixed income securities, for which generalization of findings on structured products is non-trivial.

The rest of the paper is divided in five sections. Section 1 discusses in deeper detail capital requirements and incentives for insurance firms. Section 2 presents the data. Section 3 presents the core results. Section 4 evaluates broader implications of reaching-for-yield, and Section 5 concludes.

\section{Insurance companies: Institutional setting}

\section{A. Capital requirement}

Insurance companies’ investment portfolio size and composition vary substantially depending on their main product. There are three main lines of insurance business: (i) life, (ii) property and casualty, and (iii) reinsurance. Life insurance companies have the largest assets under management. At the end of 2010, life insurance total financial assets represented $\$ 5,177$ billion, as compared to $\$ 1,403$ billion for property and casualty insurance companies (Table I). The core of insurance companies' financial assets is invested in medium- and longer-term fixed-income assets. Nearly $40 \%$ of the life insurers' financial assets are invested in corporate and foreign bonds, making them the largest institutional holder of this asset class. The precise information on the composition of bond holding by insurance firms is sparse, but according to Allstate 2010 annual statement, corporate bonds represented 38\% of its overall financial assets, while foreign government bonds only represented 3\%. 


\section{[TABLE I]}

Similar to the banks, insurance companies are subject to risk-adjusted capital requirements on their investments. Companies that fail to comply with the capital requirement may be taken over by state insurance departments. ${ }^{12}$ In principle, insurance companies are regulated at the state level. For firms with multiple subsidiaries, each subsidiary is subject to state laws and regulations. However, the regulatory standards are coordinated through NAIC. As part of this study, we contacted the department of insurance in fifty states and received an explanation about state-level regulation of capital from all but three states (Georgia, New York and New Jersey). In summary, there is some variation at the state level on statutory capital (capital required in order to retain a business license), but every state uses risk-based capital weights formulated by NAIC.

Capital requirements for credit risk are determined as a weighted sum of investments in different risk-categories. Capital weights are summarized in Table II; these risk factors had been constant over our sample period. Direct obligations of the U.S. government are exempted from capital requirement. The remaining securities are assigned to one of six risk categories (NAIC Category 1 through 6). For bonds, NAIC categories are determined based on the credit risk ratings. Issues rated AAA, AA or A are classified as Category 1. Each subsequent rating corresponds to a different NAIC risk category. Corresponding capital requirement increases exponentially. For each $\$ 100$ invested in Category 1, the insurer has to put $\$ 0.30$ of equity capital. For Category 2 (BBB), the capital requirement would be $\$ 0.96$, more than three times larger. Similar investment in Category 5 (CCC) would command \$16.96 or nearly 57 times more of equity capital. ${ }^{13}$

\footnotetext{
${ }^{12}$ Weiss Ratings reports that between 2008-2011 there were 82 insurance companies that were taken over by the state regulator (www.weissratings.com/ratings/track-record/insurer-failures.aspx).

${ }^{13}$ In addition to credit risk, total risk-based capital formula includes capital charges for equity risk, interest rate risk, affiliated and off-balance sheet risk, and other business risks. Each capital requirement component is computed separately. But rather than taking a simple sum of the components, risk-based formula rewards a company for diversifying its risks (the discount is often referred to as the "covariance adjustment”).
} 


\section{B. Incentives to reach for yield}

For reaching-for-yield to arise there must be an incentive to maximize returns, conditional on compliance with risk benchmark. Capital requirement for insurance companies leads to a target distribution of the portfolio by NAIC risk category, with the skew toward investment grade bonds. In fact, according to Allstate annual statement, as of the end of 2010, 91.6\% of its consolidated fixed income securities portfolio was rated investment grade. However, within the NAIC risk category, there is an incentive for the insurance firm and investments’ manager to maximize the yield on their investments. For example, Allstate, the largest publically held U.S. insurance company, explicitly states in its 2010 report to shareholders that: "The return on our investment portfolios is an important component of our financial results.” It also specifies that the investment strategy balances "the pursuit of competitive returns” with liquidity needs given its overall corporate capital structure.

It is important to note that promised yields—and not coupon yields, or market values—determine earnings for insurance firms. The insurance industry reports financial accounts using both statutory accounting principles (SAP) and general agreed accounting principles (GAAP). SAP accounts are presented to state insurance commissioners, and may vary slightly by state. GAAP accounts are primarily used for filings to the SEC. There is a significant overlap between the two accounting systems in the treatment of investment portfolios. Under GAAP, fixed income securities intended to be held to maturity — the majority of insurance companies' bond holdings—are accounted for using the "amortized amount”, i.e., the premium or discount at which a bond is bought, relative to its par value, is amortized evenly over time (as long as the bond is not in default). ${ }^{14}$ Under SAP, all bonds are treated this way. Under amortized treatment of bonds, the impact of non-defaulted bonds on insurers' income is the yield to maturity at which the bond was acquired. ${ }^{15}$

\footnotetext{
${ }^{14}$ An exception to this rule are property and casualty insurance companies which carry speculative grade corporate bonds (NAIC 3-6) at the lower of fair value or cost.

${ }^{15}$ See Myhr and Markham (2004) for more detail on these issues.
} 
It is also worth understanding the incentives to reach-for-yield at the manager level. According to the Insurance Asset Manager 2010 Annual Survey (World Trade Executive, 2011), in 2006 over 78\% (or \$3.25 trillion) of insurance investments were managed in-house. It is primarily insurance companies with assets under \$3 billion who outsource their portfolio management. The decision to outsource investments also varies by asset class with high-grade corporate portfolio typically managed in-house. (See NAIC, 2011 for more details.) Compensation of in-house portfolio managers tends to be similar to other asset managers: insurance company annual investment management fees for core fixed-income mandates are generally in the range of 10 to 25 basis points of assets under management. The investment manager's objective is to outperform the investment target. "If the manager outperforms the index by as much or more than the specified margin while meeting the other constraints, the investment manager would be considered to have successfully managed the investment portfolio.” (NAIC, 2011)

\section{Data}

The data for the analysis was compiled from multiple data sources and covers the 2004:Q12010:Q3 period. We have data on bond holdings from Lipper eMAXX. This database has a comprehensive coverage of quarterly fixed income holdings for insurance companies, mutual funds and pension funds. Insurance companies constitute approximately half of holdings, by number and by dollars, throughout our sample. The data contains both manager (e.g., Fidelity) and ultimate investor (e.g., Allstate). eMAXX classifies investors into categories based on type (e.g., mutual funds vs. insurance companies). The coverage of foreign bond buyers and hedge funds is limited. eMAXX does not cover households, banks, and governments. We also specifically focus on a set of large firms for which CDS spread data (see below) is likely to informative and accurate.

We exclude convertible bonds, preferred stock, other preferred securities, and government or government sponsored enterprises' bonds from our sample. Over the sample period, we observe over 4 million individual corporate bond holdings in a total of 10,045 bonds. The dollar value of holdings in the sample is $\$ 336$ billion in 2004:Q1, rising to $\$ 472$ in 2010:Q4, with a reported face value of $\$ 1$ to $\$ 1.4$ 
trillion, again depending on the quarter. The fraction of ownership covered by eMAXX is stable over time.

We examine bond holdings by insurance companies at issue as well as their trading by over time. Our new issues sample consists of holdings data for 3,709 bonds issued by 320 firms between 2004:Q3 and 2010:Q4. As illustrated in Figure 2, most of the bond issuance in our sample is investment grade. NAIC risk categories1 and 2 include 2,467 issues with a total of \$152 billion raised. Issues rated noninvestment grade, NAIC risk categories 3-6, amount to 1,242 issues (half the issue count for investment grade) and only a third in term of issue volume.

\section{[FIGURE 2]}

We collect issuer credit ratings and bond characteristics from Mergent FISD. Ratings are issued by S\&P, Moody's or Fitch, and are combined into a single rating for each bond according to NAIC rules. ${ }^{16}$ That is, if the bond is rated by two rating agencies, we use the lowest rating. If the bond is rated by all three rating agencies, we use the middle rating. Ratings are translated to a numerical scale for the purpose of averaging. The rating AAA is assigned the value $28, \mathrm{AA}+$ is $26, \mathrm{AA} 25, \mathrm{AA}-24, \mathrm{~A}+23$, etc. all the way down to CCC- which is 9, CC which is 7 and C which is 4 . Table II describes how ratings are organized into NAIC categories for the purpose of capital requirements. Because our focus is on yields and yields are not reported for floating coupon bonds, we exclude them from the sample. The majority of U.S. corporate bonds are fixed coupon bonds, so this is not something that significantly reduces our sample. We also collect promised yields at issue from Mergent FISD.

\section{[TABLE II]}

In tests of bond acquisitions by insurance companies when bonds are first issued, we consider the spread between the promised yield to maturity and a matched treasury bond, reported by MergentFISD.

\footnotetext{
${ }^{16}$ The NAIC allows ratings from a group raters (these were called acceptable ratings organizations - AROs - until 2012 when the nomenclature has changed to credit rating providers -- CRPs), For the period studied, this set of raters was a subset of the SEC's nationally recognized statistical ratings organizations (NRSROs), with some additional requirements. Moody’s, S\&P and Fitch were all AROs the whole period.
} 
When MergentFISD does not report a spread, we estimate it using the yield curve implied by other spreads reported at the same time and a bond's yield to maturity.

We also study bond acquisitions by insurance companies in the secondary market. To track yields over time, we employ the Trade Reporting and Compliance Engine (TRACE) database which reports dates, yields, prices at which bonds trade. We exclude trades that are canceled or corrected, and when multiple similar trades occur very close in time, we discard all but one transaction (assuming it is a passthrough transaction). For a given bond we calculate the median yield of all transactions taking place on the last active trading day in a given month, or quarter. We calculate bond returns as the change in price from the end of a month to the end of the next month, adding in the coupon yield. We use time series data on several return factors: the value-weighted stock market index and the risk-free rate from Ken French's website $^{17}$, the difference in returns between investment grade and high yield corporate bonds using the Lehman/Barclays index, which we call the default premium, and treasury returns to calculate the term spread. We also use the Pastor and Stambaugh (2003) liquidity factor, reported in WRDS.

CDS spreads — an alternative to yield spreads as a measure of market perceptions of credit riskcome from Credit Market Analysis, downloaded using Datastream. A CDS is essentially an insurance contract that guarantees the payoff in case a bond defaults. A higher spread — higher cost of insurance — is associated with higher default probability. The CDS spread is a quarterly premium (quoted on annualized basis) that the CDS buyer pays the seller. In exchange, the seller commits to pay the buyer bond's face value upon bond's default. We use the data for 5-year senior default spreads, the most liquid segment of the market. In the last ten years, the CDS market has become increasingly important. In 2001 notional value of CDS market was $\$ 630$ billion; in 2009, despite retraction of the market, the notional

\footnotetext{
${ }^{17}$ Based on Longstaff, Mittal and Neis (2007), some studies have used the swap rate instead of treasury rate as a benchmark for returns. We have tried this alternative throughout, with very similar results.
} 
amount was $\$ 36$ trillion. $^{18}$ Yet, for most bonds, the CDS market remains illiquid; this is one reason why CDS spreads are slow to be adopted in contracts and regulation as a measure of risk. We focus on bond issuers that were part of the CDX Markit index, one of the primary tradable index families, between the index inception in 2003 and 2010. ${ }^{19}$ The inclusion in the index is determined by liquidity rankings, constrained so that the index has a balanced industry representation. ${ }^{20}$ One thing to keep in mind is that CDS is not specific to individual bonds; upon default several fixed income securities might be considered to be a deliverable under the contract.

Table III compares sample bonds across different CDS quartiles. We assign all issuers to CDS quartiles, from low to high, among all firms in a ratings group in a given quarter. (In the analysis, we will use a continuous measure of CDS spread. In this table, we summarize it by quartiles for purposes of expositions.) Quartile 4 (high CDS spreads within NAIC category) bonds are characterized by higher yields, but not the longer maturities, than low CDS bonds. The high CDS bonds' issuers have lower ratings, higher book leverage and lower return on assets (and higher CDS spreads, obviously). The size of issuers is not statistically different. This is consistent with the CDS spread capturing financial performance of the company that might not be fully reflected in the credit ratings. Table III is conditional on investment grade bonds (NAIC category 1 and 2), but as one can see with the exception of the lowest CDS quartile, there are no differences in average credit ratings across the CDS categories.

[TABLE III]

\footnotetext{
${ }^{18}$ U.S. Government Accountability Office, "Regulatory Oversight and Recent Initiatives to Address Risk Posed by Credit Default Swaps", testimony before the Subcommittee on Capital Markets, Insurance, and Government Sponsored Enterprises.

${ }^{19}$ Conditioning our sample on inclusion in the index at any point during the eight year period might generate a selection bias. A bond issued by a firm that is not a member of the CDX index in 2004, but will be included in the 2009, will appear in our sample. This should not affect the composition of ownership, but might hypothetically result in an upward bias for average realized returns on the bonds after issuance. We will not use average returns for our tests (but we will compare returns of subgroups).

${ }^{20}$ We include bonds that had been either part of investment grade (CDX.NA.IG) or non-investment grade index (CDX.NA.HY), Series 1 through 16. Series 1 of CDX Markit Index was rolled out in October 2003.
} 
We compute two measures of bond liquidity: the log of total transaction volumes relative to outstanding par value in the preceding quarter (based on TRACE), and the log of the number of investors reporting changed positions in the bond over the preceding quarter (based on eMAXX). We also estimate bond durations, based on detailed cash flow (e.g., coupon times and amounts) data from Mergent FISD and yields (from Mergent FISD at issue or from eMAXX transactions for later dates).

Finally, we collect additional information about insurance companies. First, we gather daily stock return data for publicly listed insurers for the 2001 to 2011 period from CRSP, and calculate betas and volatilities as well as the stock returns during the crisis. The average stock return for the crisis period, defined as June 2008 to February 2009, is $-46.3 \%$ and the standard deviation is $30.6 \%$. We also collect regulatory capital for insurance companies from S\&P CapitalIQ. Our measure of regulatory capital cushion surplus is the difference between required capital and reported capital, normalized with book value of assets. When a subsidiary company appears in our data, we use the ultimate parent's capital. Across 97 parent companies, the mean of 2004 capital surplus is $17 \%$ and the standard deviation is $11 \%$.

To characterize insurers, we also define an indicator for publicly listed firms, and a lagged measure of leverage (the ratio of assets to equity) and size (the log of asset book value). Mean leverage is 8.8 and standard deviation 26.0 (this measure includes policy liabilities). Mean book assets is $\$ 70$ billion. We collect data on governance from Dlugosz, Fahlenbrach, Gompers and Metrick (2006). For each public insurance company, we update their block count from 2001 (the last date they provide data for) using 13-F filings. We use total ownership in block holdings (as a fraction of outstanding shares) as a measure of governance. For each insurance company, we calculate the average yield on their investment grade portfolio as a measure of the institution's propensity to reach for yield. To avoid putting excessive weight on a few bond positions, we calculate the equal-weighted average treasury spread of each insurer's precrisis bonds acquisitions in NAIC 1 and 2 (i.e., bonds rated AAA, AA, A and BBB).

\section{Results}

A. Benchmark results: Holdings at bonds issuance 
Our first set of results focuses on investment choices at the bond issuance. As mentioned earlier, the core of insurance assets are managed by life insurers. Unlike property and casualty companies, life insurers to do not anticipate paying benefits in a short run on their average policy, so most of their investments are held to maturity. As a result, insurance portfolios have little turnover. According to NAIC (2011), portfolio turnover is in the range of 20 -25\% per year or less for the core fixed-income insurers' holdings. That is why looking at investment choices at issuance is central for understanding their behavior. Overall, total new issues in our sample amount to approximately $\$ 2$ trillion. We have holding data on 6,154 bonds of which 3,807 are issued during the 2004:Q3-2010:Q3 sample period.

We should note that the holding data is quarterly, and we do not observe exact dates when holdings have changed. A large fraction of the bonds appear in insurance companies' portfolio in the quarter immediately following bond issuance helps to ameliorate this problem. Because there is fairly little turnover, the bond positions we observe in the first quarter were most likely largely acquired at issue. It is very likely that the yield at issuance (as reported in Mergent FISD) is the yield at which bonds were acquired. The reporting date is not standardized for different investors. To allow for reporting delays, we have also included bond holdings in the second calendar quarter following the date of bond issuance when the first quarter shows no holdings, but this does not change results.

To test if insurance companies reach for yield by we compare their bond acquisitions to those of other institutions. Figure 3 documents the average bond yields in portfolios of insurance, pension funds and mutual funds in the pre-crisis period and crisis/post-crisis period, respectively. Comparing both mutual funds and pension funds, it’s clear that insurance companies acquired high yield bonds during the pre-crisis period. Of course, these comparisons do not control for other factors, and discard all heterogeneity in yields. This can be addressed in regressions.

\section{[FIGURE 3]}

Regression results for bond purchases at issuance are reported in Tables IV (yields) and V (CDS spreads). Each observation in the sample corresponds to a different bond. The dependent variable is a sum of insurance investors' holdings of a given bond scaled by the total recorded holdings in the eMAXX 
data; insurance companies’ investment decision is benchmarked against aggregate holdings of mutual and pension funds. We cluster standard errors by issuer because same companies can have several issues over our sample. (In addition, CDS contracts are not specific to the deliverable.)

Both Table IV and V report results for pre-crisis (2004:Q3-2007:Q2, specifications (1) - (4)) and crisis period (2007:Q3-2010:Q4, specifications (5)-(7)). ${ }^{21}$ In Table IV the explanatory variable of interest is the treasury spread at issuance. Specifications (1)-(3) show that, as compared to other institutional investors, the propensity of insurance companies to invest in new bonds is an increasing function of the yield. In other words, there is reaching-for-yield. The first column of Table IV reports the baseline regression. The coefficient on the treasury spread is positive and significantly different from zero, indicating that in the pre-crisis period, within NAIC 1 and 2, bonds with higher yields ended up with insurance investors, more than other bonds. The coefficient estimate implies that a 100 basis point increase in the yield (a standard deviation is 128 bps) corresponds to a $7 \%$ higher fraction of insurance holdings. This corresponds to a quarter of a standard deviation of the dependent variable.

In specifications (1)-(3), the sample is constrained to bonds rated investment grade at issuance (NAIC risk category 1 and 2). Because NAIC 1 and NAIC 2 have different capital treatment, we include a dummy variable equal one for bonds rated $\mathrm{BBB}+, \mathrm{BBB}$ or BBB- (NAIC2) and zero otherwise. In columns (2) and (3) we add controls for bond and issuer characteristics. The concern is that insurance companies (or the control investor group) have preferences for certain bond or issuer characteristics. If these features are correlated with yield, reaching-for-yield may be hard to distinguish from the investors' preferences. In column (2), we control for bond duration and offering amount. The offering amount captures the size of the issue (insurance companies may ignore small issues) and liquidity (larger bond

\footnotetext{
${ }^{21}$ Because eMAXX has comprehensive coverage we detect new issues when a bond appears in the data for the first time. New issues for 2004:Q1 and 2004:Q2 are difficult to identify from the data because old bonds also appear for the first time in these quarters. Hence, the sample starts in 2004:Q3.
} 
issues are more liquid). ${ }^{22}$ The negative coefficient on issue size is consistent with a tolerance for higher liquidity among insurance investors. This is consistent with their long holding periods and investment horizons; i.e., it makes sense for insurance investors to hold the least liquid bonds if they can get compensated for this. The limited explanatory power of issue size is also consistent with there being limited scope to reach for yield by loading up on illiquidity alone (see Longstaff, Mithal and Neis, 2007). In column (3), we extend the set of controls to include ratings (AAA, AA, A, BBB) interacted with year of the bond issuance. (The dummy for NAIC 2 drops out in this specification.) Fixed effects absorb a lot of the variation in the sample, raising the $R$-squared from $17 \%$ to $31 \%$. But the coefficient of interest remains positive, economically large and statistically significant.

\section{[TABLE IV]}

Specification (4) is the same as specification (3), but applied to non-investment (speculative) grade issues as opposed to investment grade. The coefficient on the yield is now statistically insignificant, which is consistent the hypothesis that reaching-for-yield should be less appealing for lower ratings (where the probability of downgrades and capital requirements are higher).

In columns (5) through (7) we repeat the same analysis for the "crisis" period, defined as the period following second half of 2007 (2007:Q3-2010:Q4). ${ }^{23}$ The idea is to allow for possible changes in investment behavior during the financial crisis. Specifically, we expect reaching-for-yield over this period to become weaker due to rise in downgrade probabilities, increase in scrutiny, rise in awareness of previously neglected risks, or a shift in risk-preferences. The coefficient on yield is reversed during the crisis. As discussed in the introduction, during the economic downturn, the incentives to reach for yield are likely to be much weaker. This is consistent with the time-varying pattern identified in the data. This

\footnotetext{
${ }^{22}$ In our tests of the secondary market (trades of bonds after issuance), we include explicit controls for bond liquidity.

${ }^{23}$ Arguably, the financial crisis was over before this period ends; the National Bureau of Economic Research dates the associated economic recession as December 2007 through June 2009. We revisit detailed time pattern below in Table VII.
} 
finding also helps with the interpretation of our results because it means that time-invariant institutional differences—e.g., regulation, superior investment ability, or institutional investment preferences—cannot explain our findings.

The results reported in Table IV imply that insurance companies, relative to other investor categories, favor high-yield bonds conditional on the benchmark risk category. This is consistent with reaching-for-yield, i.e. a preference for riskier bonds within a given category. We next turn to CDS spreads. The market for CDS contracts, on the firms in our sample, is liquid and potentially attracts a broader investment base. Therefore, it can provide an informative alternative measure of risk.

In Table $\mathrm{V}$ we repeat the analysis using logarithm of the median CDS spread in the quarter of issue as the main explanatory variable. ${ }^{24}$ We expect the same sign on spreads as on yields. In all of the benchmark specifications, the holdings of insurance companies load positively on the CDS spread. In column (1), which presents the baseline results, a one standard deviation increase in the CDS spread (an $80 \%$ increase in the log of the spread) corresponds to a 5.8 percentage point increase in the insurance share of holdings at issue. The coefficient estimates are even larger in we include controls for maturity, issue size, year of issuance and credit rating (columns 2 and 3). As before, this result only holds for investment grade bonds and disappears during the crisis.

\section{[TABLE V]}

Note, that the yield and CDS spreads are not always available, so the sample sizes differ between Table IV and Table V. In Figure 4, we examine the relation between the two variables for all bond issues where both are available. The relationship is positive and significant. This helps with the concern that the results shown for yields and CDS spreads correspond to different samples of issuers. It also highlights

\footnotetext{
${ }^{24}$ In order to have a result in the form of an elasticity, it is convenient to use the log of the CDS spread, and logs avoids a disproportionate influence on regression by a few outliers (results are similar with the spread itself).We use median across daily observations to account for outliers, but the results are the same using the average spread.
} 
that yields and CDS spreads can differ, suggesting that it is a conservative approach to use both as measures of risk taking in bond portfolios.

\section{[FIGURE 4]}

Taken together, the results on insurance holdings of corporate bonds at issue suggest that, conditional on regulatory risk category, insurance companies have a preference for higher yielding, higher risk bonds, i.e., tend to reach for yield. Two possible alternative interpretations should be considered: (i) high yields reflect premium for low liquidity and liquidity risk; and that high yields are the result of bond-picking ability and market mispricing. We turn to each of these in turn.

The dependent variable in Tables IV and V is the holdings of insurance companies scaled by the total holdings of insurance companies, mutual funds and pension funds. The variable could be sensitive to shifts in the relative demand by these investor categories, e.g. due to fund flows or the ability to lever up in response to investment. For example, if insurance companies have the ability to raise funds in response to investment opportunities they might invest (relatively) more at times when yields are high. Mutual funds and pension funds have little to no leverage, so it is unlikely that they can time the market in this way. This also appears to be the case for the insurance industry.

Figure 5 shows the capital structure of U.S. insurance companies. In total, over $70 \%$ of insurance companies' liabilities are composed of the obligations generated by underwriting. Long-term debt represents $5 \%$ and short-term debt only $1 \%$ of liabilities. The minimal amount of debt indicates that timevarying investment patterns by insurance companies, as compared to mutual funds and pension funds, cannot be explained by fluctuation in capital structure.

\section{[FIGURE 5]}

\section{B. Benchmark results: Secondary market trading}

Most of the investment activity in fixed income occurs at issuance. However, there is a secondary market in corporate bonds. If our hypotheses are correct, then reaching-for-yield should also manifest itself in secondary market trading. There are several additional advantages to looking at 
secondary market trading. Because we can follow a bond over time, it allows us to rule out cross-sectional differences in characteristics. Furthermore, since illiquid bonds are rarely traded, and since we can control for better liquidity measures, reaching in the secondary market (controlling for liquidity measures) is unlikely to reflect a liquidity premium. We also no longer look at the insurance firms' investment decisions as compared to other institutional investors, but instead explore their preference for the same bond as its market-assessed risk profile evolves.

To test reaching-for-yield in the secondary market, we look at how the holdings of insurance companies change between successive quarters. The sample is now a panel (bond times quarter), as opposed to a cross-section. We use yields to maturity on the over-the-counter secondary market transactions reported in TRACE. The results are reported in Table VI. The dependent variable is the log quarterly change in the value of all insurance companies' holdings of a bond. (Maturing bonds are excluded). In order to control for time-invariant and time-varying issuer characteristics we include firmtimes-quarter fixed effects. We also include controls for key time-varying bond characteristics: duration and liquidity. We include two measures of liquidity: the log of total transaction volumes relative to outstanding par value in the preceding quarter (based on TRACE), and the log of the number of investors reporting changed positions in the bond over the preceding quarter (based on eMAXX). Note however that the analysis includes firm-times-quarter fixed effects, controls for liquidity pick up within firmquarter variation in liquidity, which may not be important.

\section{[TABLE VI]}

The economic and statistical significance of the benchmark result, Table VI specification (1), indicates that insurance companies buy more (or sell less) of outstanding bonds that have a higher yield. A one hundred basis point increase in a bond's yield corresponds to a predicted increase in insurance acquisitions in the secondary markets of $4 \%$ of insurance holdings. This is consistent with findings at issue: insurance companies systematically buy high yield corporate bonds (within investment grade).

We find that the reaching-for-yield result is specific to the pre-crisis period. As mentioned earlier, the time variation in reaching-for-yield is important for the interpretation of our results. In Table VII, we 
extent the benchmark specification to include quarter dummies interacted with the yield to maturity. These time-varying coefficient estimates can capture the evolution of reaching behavior over time. Since there are relatively few new issues in some quarters, these coefficients may be hard to estimate precisely. Nevertheless, we find a consistent pattern in the quarter-by-quarter results. The coefficients indicate pronounced cyclicality in reaching-for-yield. We find consistently positive coefficients for the pre-crisis period, mixed signs during the crisis (as defined by the NBER recession indicator), and again positive coefficients after the crisis has abated. ${ }^{25}$

\section{[TABLE VII]}

Based on the framework presented in Section 2, these regression results are consistent with reaching-for-yield driven by regulatory capital requirement. The return of positive slope estimates in the short post-crisis period we have in our data suggests that reaching was not unique to the 2004-2007 period, but may in fact be a pattern that appears repeatedly during economic expansions. Because the post-crisis sample is short, this is a tentative conclusion.

\section{Insurance firms' portfolio returns}

We find that insurance companies systematically prefer high yielding investment grade bonds, compared to other investors (pension funds and mutual funds). We argue these higher yields may reflect risk. But higher yields can also be the sign of bond underpricing. Could it be that the higher yield on bonds held by insurance companies are just a reflection of their superior bond-picking or just better access to underpriced bonds? There are several reasons why this alternative interpretation is weak. First, we observe no reaching-for-yield in speculative grade bonds. The absence of reaching-for-yield in speculative grade is hard to reconcile with a general ability to identify underpriced bonds. Second, the reaching-for-yield that we document prior to the crisis disappears during the economic downturn. This

\footnotetext{
${ }^{25}$ Notably, the drop in coefficient in 2005:Q2 coincides with the downgrade of GM and Ford to junk, an important shock to the bond market.
} 
observation appears inconsistent with investment ability as an explanation of reaching-for-yield; it seems unlikely that bond underpricing disappeared in the crisis, since there were massive falls in bond prices generally at that time.

That said, we now address the hypothesis of superior investment ability directly by evaluating bond performance. We focus on investment grade bonds issued between 2004 and 2007, the period when we observe reaching-for-yield. Each month, all newly issued bonds are sorted based on the fraction acquired by insurance companies (relative to mutual funds and pension funds). Bonds are then divided into two portfolios, above and below the median insurance share ("high insurance holdings" and "low insurance holdings”.) Using coupon yield from Mergent FISD and end-of-the-month transaction prices from TRACE, we calculate equal-weighted monthly returns on bonds acquired within 1-year. On average, the excess return is negative for the portfolio with high insurance holdings and positive for the low insurance holdings portfolio (the difference is not statistically significant at the conventional levels). The standard deviation of excess returns is higher for the high insurance holdings portfolio (157 bps) than for the low insurance holdings portfolio (86 bps). An F-test rejects that the two standard deviations are similar at the $1 \%$ significance level. ${ }^{26}$ We next turn to exposure to risk factors. Tests factor loadings for the two portfolios are reported in Table VIII.

\section{[TABLE VIII]}

Results in Table VIII column (1) and (4) confirm that in a CAPM setting, insurance companies’ investment choices generate risky returns: the beta is significantly positive only for the portfolio of bonds with high insurance holdings. In columns (2) and (5) we add the two bond market factors: default and term premium. ${ }^{27}$ In columns (3) and (6) we include the Pastor Stambaugh (2003) liquidity factor, which

\footnotetext{
${ }^{26}$ In unreported results, we have varied the methodology for these tests. The findings are robust to using 24-month holding periods, including the Fama French SMB and HML factors (which neither portfolio loads on), using value weighted returns instead of equal weighted, and allowing for first order serially correlated errors. Including 2008 returns raises the beta estimate for both portfolios (to 0.51 and 0.29 , respectively).

${ }^{27}$ This factor model is based on Bessembinder, Kahle, Maxwell and Xu (2009).
} 
neither portfolio loads on. Together, these regression results do not suggest any superior bond-picking ability (“ability to generate alpha”) of insurance companies. When controlling for default premium and term spread, we can reject a non-negative alpha for the high insurance holdings portfolio at the $10 \%$ level. Regardless of model, the portfolio with low insurance holdings has an intercept close to zero. In view of these tests, higher yields on the bonds that are preferred by insurance firms reflect market risk, but not ability.

\section{Insurance firms' characteristics}

To further understand the main drivers of reaching-for-yield, we now turn to individual insurance firms' investment decisions. Specifically, we want to test how reaching-for-yield relates to regulatory capital constraints, public listing status, corporate governance, and financial leverage. If some firms reach for yield in order to increase the amount of risk in their bond portfolio relative to the regulatory capital required, we would expect portfolio yields to be higher among firms with lower cushions of regulatory (risk adjusted) capital. If risk-shifting is the driver behind reaching for yield, we would expect portfolio yields to be higher among firms with higher financial leverage. If reaching for yield is a reflection of agency problems, we would expect firms with better corporate governance to have lower portfolio yields.

Table IX reports results from panel regressions of insurance companies' corporate bond purchases at issue for each year from 2004-2007. To capture reaching for yield, we use the average yield within a capital regulation category. The dependent variable is the equal-weighted average treasury spread of acquired bonds in NAIC 1 and 2. Due to lack of data on regulatory capital, we lose several observations, including the majority of private firms. There are 107 parent companies with regulatory capital data for at least one year, of which 85 are public. ${ }^{28}$

\footnotetext{
${ }^{28}$ In unreported regressions, we have used average promised yield to maturity across bonds and the issuer's CDS spread as dependent variables. The results are similar. We have also used value-weighted results, with similar results (in some cases, a few bonds dominate the value of a portfolio).
} 
The explanatory variables of interest are (1) regulatory capital surplus, i.e. the difference between regulatory capital and required regulatory capital normalized by book assets, and (2) the fraction of shares held in large blocks ${ }^{29}$. Unlike other measures of governance, the share of block holders changes over time. These variables can tell us if low regulatory capital and/or weak corporate governance predicts high yields in the investment grade bond portfolio across insurance companies. The capital surplus ratio ranges from $1.1 \%$ to $61.4 \%$, with an average of $15.2 \%$ and standard deviation of $10.0 \%$. Total ownership in block holdings ranges from zero to $71.5 \%$ (the number of individual blocks ranges from zero to six). Average ownership in blocks is $17.5 \%$, and the standard deviation is $15.9 \%$.

\section{[TABLE IX]}

In column (1), we report a simple regression of the average treasury spread of investment grade bonds acquired on regulatory capital surplus. The coefficient is negative and significant. A one standard deviation decrease in the capital surplus (10\%) corresponds to a 5 basis points increase in the spread of an insurance company's bond portfolio. This is one-third of the cross-firm standard deviation of yield spreads. The results are consistent with the regulation hypothesis: firms with lower capital surplus are more likely to reach for yield. This is also consistent with the finding of Ellul, Jotikasthira and Lundblad (2011) that more capital-constrained insurance firms tend to participate in fire sales around bond downgrades, likely reflecting an attempt to avoid higher capital requirements.

In column (2) we control for whether a firm is publicly traded, to examine whether such firms reach for yield due to the incentives generated by reporting and earnings management, as well as leverage and size. The coefficient estimate on the public status indicator is insignificant, suggesting reaching for yield is not more pronounced among publicly traded firms. Thus, quarterly earnings pressure is not likely the main driver of reaching behavior. Highly levered firms do not appear to buy higher yielding bonds. This suggests that risk shifting in the Jensen and Meckling (1976) sense may not be the driver of reaching

\footnotetext{
${ }^{29}$ See data section for definitions.
} 
for yield behavior. ${ }^{30}$ Also, column (2) documents that large firms do reach for yield more. This is important econometrically because of the correlation between size and regulatory capital (small firms tend to have bigger capital cushions). The regulatory capital result remains significant in this regression.

In column (3), we examine the effect of having large block-holders who can provide active monitoring of a firm. The sample size is smaller, because we only have governance data for public firms. The coefficient estimate for block holdings is negative and significant, suggesting that strong owners reduce reaching. ${ }^{31}$ An additional $16 \%$ held in blocks (a standard deviation) is associated with a 4.5 basis points increase in portfolio yields, similar to the magnitude associated with capital surplus. We interpret this as consistent with the hypothesis that private contracting frictions can drive reaching for yield. In column (4), we include the set of control variables (the public status indicator drops out since we only have governance data for public firms). Again, the coefficient on size is positive and significant at the 10\% level. Leverage does not appear associated with higher bond yields.

We run a horse race between the two key variables in column (5), including the control variables. Both coefficients of interest are negative and significant, although less so (p-values of $6 \%$ and $7 \%$, respectively), partially due to co-linearity (the correlation coefficient for the two variables is 0.38 ). Holding leverage fixed, the yield difference between a firm at the $75^{\text {th }}$ percentile of both capital and block ownership, and one at the $25^{\text {th }}$ percentile of both, is 19 basis points, roughly a fifth of the median yield spread. Overall, the cross-sectional findings provide support for both risk preference and weak incentives: firms with both aggressive capital management and weak governance take on much more risk.

\footnotetext{
${ }^{30}$ Because insurance companies do not use much leverage (apart from policy-related liabilities), this may not be the right setting for testing the general relevance of risk shifting vis-à-vis debt investors.

${ }^{31}$ Block holders may also be less diversified than dispersed owners, therefore being more reluctant for the firm to take on idiosyncratic risk. This would also explain firms with block owners being less risky. However, since we find that much of the risk taken on is systematic (see Table VII above), this may not be an important distinction (undiversified owners have no reason to be more averse to systematic risk).
} 


\section{Implications of Reaching for Yield}

We now turn to an assessment of the welfare consequences of reaching-for-yield. As we had shown, reaching-for-yield has a pronounced pro-cyclical pattern, being at its strongest during the peak of the credit boom and disappearing in the second half of 2007. Understanding the connection between reaching-for-yield and the business cycle is an important question. In what follows, we provide partial evidence for two channels through which reaching-for-yield could have broader implication for the economy: first, concentration of systemic risk in the insurance firms' portfolios; and, second, the potential effect on the allocation of credit supply.

\section{A. Direct implications: Insurance company exposure to systemic risk}

In Table VIII we had shown that, when reaching for yield, insurance companies select bonds with higher systemic risk (higher beta). This is consistent with Iannotta and Pennacchi’s (2012), Gurrieri and Kondor (2012), and Frazzini and Pedersen's (2011) models. In this section we extend this result by looking at the overall insurance firms' performance. Indeed, the 2008 financial crisis involved considerable losses for many insurance companies. Three companies (AIG, Hartford Financial Services and Lincoln National) received government support under the Troubled Asset Relief Program (TARP), and one (AIG) was partially taken over by the Federal Reserve in September 2008. If reaching for yield reflects higher risk taking, in a cross-section, we might expect bigger losses of equity value for insurance companies that had reached more in their bond portfolios. This appears to be the case. In Figure 6, we plot the stock returns of public insurance companies for the nine months June 2008 to February 2009 against the average spread of the same companies NAIC 1 bonds. The returns range from -99\% (AIG) to 38\% (Industrial Alliance Insurance and Financial Services). As predicted, there is a strong negative relation between crisis stock performance and the amount of reaching for yield.

\section{[FIGURE 6]}

In Table X, we examine crisis returns in a multivariate setting. The specification in column (1) replicates the pattern observed in Figure 6, and shows that the negative relation between pre-crisis 
reaching and crisis returns is statistically significant. For a standard deviation increase in bond spreads(18 basis points), a firm is predicted to have lost $14.6 \%$ more equity value in the crisis (half of the cross-firm standard deviation of crisis returns). In column (2), we use the average pre-crisis offering yield instead of the yield spread, with similar results (the standard deviation for yields is higher, implying that the economic magnitude is slightly larger).

\section{[TABLE X]}

In columns (2) and (3), we replicate the result for excess returns, defined as the raw return minus equity beta multiplied by $-47.5 \%$ (the market's return in the period). This is likely over-controlling since higher risk in an insurance company's investment portfolio could affect its systematic risk (beta). The results indicate that reaching is additionally associated with negative excess returns. In other words, the insurers with most reaching for yield showed negative returns even beyond what their systematic risk would have predicted. In columns (5) and (6) we use raw returns as dependent variable, and allow for the coefficient on beta to be statistically determined. We also include controls for stock price volatility and a TARP recipient (AIG, Hartford Financial Services, Lincoln National) indicator. The negative correlation remains.

The negative returns during the crisis that we document for firms more engaged in reaching for yield can represent not only losses on the riskier bond portfolios but also losses due to higher risk choices elsewhere (e.g., reaching for yield in structured products). In either case, the results suggest that reaching for yield is not innocuous in terms of the ultimate risks taken on by insurance companies.

\section{B. Indirect implications: Corporate bond issuance}

Because insurance companies are large participants in the corporate bond market, reaching for yield may generate a shift in the supply of credit to individual firms. Whether such a shift will manifest in the price or quantity of credit presumably depends on the demand elasticity of issuers. If issuers change 
issuance to respond to supply conditions, the response may be more visible in quantities than in yield spreads. ${ }^{32}$ We therefore focus on volumes. To examine this, we sort all NAIC 2 corporate bond issuers (i.e., firms that previously issued a bond) into quartiles based on their previous quarter CDS spreads. We then calculate the share of bond issuance, by number or by value, within NAIC 2 (we use this category as there is more consistent issuance in NAIC 2 than NAIC 1 throughout our sample period), which is done by issuers in the top half of CDS spreads. We compare this to the time series of insurance companies' reaching for yield, as identified in Table VII. This time series are depicted in Figure 7.

\section{[FIGURE 7]}

The pattern in Figure 7 shows a positive association between high CDS firm's issue share and insurance reaching for yield. The correlation between reaching and the high CDS share is 0.24 (amount) and 0.37 (number), statistically significant at the $10 \%$ level. This indicates that high yield issuers within the BBB rating category issue more (relative to low yield issuers in the same rating category) at times when insurance companies reach for yield. These correlations are based on few observations and reflect a period of upheaval in credit markets, so they should be interpreted as suggestive only. Taken as such, the time series pattern is consistent with an issuance response by corporations. In other words, the flow of corporate credit appears to be affected by reaching for yield.

\section{Conclusions}

It has been argued that reaching-for-yield—investors’ propensity to buy riskier bonds in order to achieve higher yields-may have been an important driver behind the dislocations in the credit market during financial booms, such as 2004-2007. How reaching-for-yield works and where it manifests is not well understood. In this paper, we examine reaching-for-yield in the corporate bond market by looking among insurance companies, the largest institutional investor in this market. Insurance companies have

\footnotetext{
32 There is prior evidence that corporate bond issuers are willing and able to adjust issuance to market conditions (Kashyap, Stein and Wilcox, 1993; Becker and Ivashina, 2011).
} 
capital requirements tied to the credit ratings of their investments. We show that, conditional on ratings, insurance portfolios are systematically biased toward higher yield, higher CDS bonds. This result holds both at issue and in the secondary market.

We address several alternative interpretations of our findings. One concern is that high yield is correlated with some bond characteristics that might be attractive to insurance companies for other reasons. Such explanations would have to fit the time series variation we document in reaching-for-yield. Furthermore, when looking at secondary market trading, we follow a bond over time, thus ruling out any cross-sectional differences in characteristics. Another concern is that insurance companies might have the ability to make superior investments in fixed income ("generate alpha”). If high yield bonds are underpriced on average, this investment ability would result in portfolios tilted toward higher yielding bonds. However, we implement a direct test of portfolio "alphas" and show that, as a group, insurance companies that reach for yield do not generate higher performance, but do appear to hold riskier bonds.

We provide some evidence on the drivers of reaching for yield, suggesting that low regulatory capital and weak corporate governance are associated with more aggressive reaching. We conclude that regulation as well as private contracting frictions can drive this behavior.

It is commonly believed that reaching for yield contributes to the cyclicality of credit supply and, therefore, to the real economic cycle. Consistent with this statement, we find that reaching-for-yield is pro-cyclical, disappearing in the second half of 2007 and coming back in 2009. We further provide evidence for two channels through which reaching-for-yield appears to affect the broader economy. Specifically, periods of reaching for yield by insurance companies appear to lead to higher issuance of risky assets by corporations.

We also show that insurance firms tend to buy bonds with higher systemic risk. In addition, from the portfolio prospective, insurance firms that had the highest tendency to reach for yield in the period preceding 2007-2008 financial crisis had performed the worst in the recession period. Although insurance firms appear to be less sensitive to runs than banks, as banks, they have liabilities to a broad population base making concentration of risk within insurance portfolio of a macroeconomic concern. 


\section{References}

Acharya, V. and M. Richardson, 2009, “Causes of the Financial Crisis,” Critical Review 21, 195-210.

Bao, J., J. Pan and J. Wang, 2011, “The Illiquidity of Corporate Bonds,” Journal of Finance 66 (3), 911946.

Becker, G., 1968, “Crime and Punishment: An Economic Approach,” Journal of Political Economy, 76(2), 169-217.

Becker, B., and V. Ivashina, 2011, “Cyclicality of Credit Supply: Firm Level Evidence”, HBS working paper.

Becker, B., and T. Milbourn, 2011, “How Did Increased Competition Affect Credit Ratings?” Journal of Financial Economics 101(1), 2011-2012.

Benmelech, E., and J. Dlugosz, 2009, “The Alchemy of CDO Credit Ratings,” Journal of Monetary Economics 56(5), 617-634.

Bessembinder, H., K. Kahle, E. Maxwell and D. Xu, 2009, “Measuring Abnormal Bond Performance”, Review of Financial Studies, 22(10), 4219-4258.

Bongaerts, D., F. De Jong and J. Driessen, 2011, “Derivative Pricing with Liquidity Risk: Theory and Evidence from the Credit Default Swap Market”, Journal of Finance, 66(1), 203-240.

Chernenko, S., and A. Sunderam, 2012, “The Real Consequences of Market Segmentation,” Review of Financial Studies (forthcoming).

Chevalier, J., and G. Ellison, 1995, “Risk Taking by Mutual Funds as a Response to Incentives”, Journal of Political Economy, 105(6), 1167-1200.

Chevalier, J., and G. Ellison, 1999, “Career Concerns of Mutual Fund Managers”, Quarterly Journal of Economics, 114(2), 389-432.

Cornaggia J., and K. Cornaggia, 2011, “Does Bond Market Want Informative Credit Ratings?”, Working paper.

Coval, J., J. Jurek, and E. Stafford, 2009, “Economic Catastrophe Bonds,” American Economic Review 99 (3), 628-666.

Cox, A. 1967, “Regulation of Interest on Deposits: An Historical Review,” Journal of Finance 22(2), 274296.

Dlugosz, J., R. Fahlenbrach, P. Gompers, and A. Metrick, 2006, “Large blocks of stock: Prevalence, size, and measurement”, Journal of Corporate Finance, 12 (3), June, 594-618.

Edwards, A., L. Harris, and M. Piwowar, 2007, “Corporate Bond Market Transaction Costs and Transparency,” Journal of Finance 62(3), 1421-1451. 
Ellul, A., C. Jotikasthira and C. Lundblad, 2011, "Regulatory Pressure and Fire Sales in the Corporate Bond Market,” Journal of Financial Economics 101, 596-620.

Frazzini, A., and L. Pedersen, 2011, “Betting against Beta,” Working paper.

Gennaioli, N., A. Shleifer and R. Vishny, 2012, "Neglected Risks, Financial Innovation, and Financial Fragility,” Journal of Financial Economics (forthcoming).

Gurrieri, Veronica, and Péter Kondor, 2012, "Fund Managers, Career Concerns and Asset Price Volatility,” American Economic Review 102(5), 1986-2017.

Iannotta, G., and G. Pennacchi, 2012, “Bank Regulation, Credit Rating, and Systemic Risk,” Working paper.

Jensen, M., and W. Meckling, 1976, “Theory of the Firm: Managerial Behavior, Agency Costs and Ownership Structure,” Journal of Financial Economics 3, 305-360.

Kashyap, A., and J. Stein, 2004, “Cyclical Implications of the Basel II Capital Standards,” Economic Perspectives, 28(1), 18-31.

Kashyap, A., J. Stein, and D Wilcox, 1993, “Monetary Policy and Credit Conditions: Evidence from the Composition of External Finance”, American Economic Review 83, 221-256.

Kacperczyk, M., and P. Schnabl, 2012, “How Safe are Money Market Mutual Funds,” Working paper.

Keys, B., T. Mukherjee, A. Seru and V. Vig, 2010, “Securitization Lead to Lax Screening? Evidence from Subprime Loans,” Quarterly Journal of Economics 125(1), 307-362.

Koijen, R., and M. Yogo, 2012, The Cost of Financial Frictions for Life Insurers, Working paper.

Laffont, J., and J. Tirole, 1993, A Theory of Incentives in Procurement and Regulation, MIT Press, Cambridge.

Longstaff, F., S. Mithal and E. Neis, 2007, “Corporate Yield Spreads: Default Risk or Liquidity? New Evidence from the Credit Default Swap Market”, Journal of Finance, 60(5), 2213-2253.

Moody’s Investor Service, 2002, Understanding Moody’s Corporate Bond Ratings and Rating Process. Myhr, A., and J. Markham, 2004, Insurance Operations, regulation, and Statutory Accounting, Second Edition, American Institute for Chartered property Casualty Underwriters/Insurance Institute of America, Pennsylvania.

NAIC, “Insurance Asset Management: Internal, External or Both?” NAIC Capital Markets Special Report, August 26, 2011 (http://www.naic.org/capital_markets_archive/110826.htm).

Nissim, D., 2010, Analysis and Valuation of Insurance Companies, Center for Excellence in Accounting and Security Analysis.

Pastor, Lubos, and R. F. Stambaugh, 2003, “Liquidity risk and expected stock returns”, Journal of Political Economy 111, 642-685. 
Peltzman, S., 1975, “The Effects of Automobile Safety Regulation”, Journal of Political Economy, 83(4), 677-725.

Pigou, Arthur C. 1938, The Economics of Welfare, 4th ed. London: Macmillan and Co.

Rajan, R. 2010, Fault Lines, Princeton University Press.

World Trade Executive, 2011, IFI Insurance Asset Manager: Annual Survey 2010.

Yellen, J., 2011, Remarks at the International Conference: Real and Financial Linkage and Monetary

Policy, Bank of Japan, http://www.federalreserve.gov/newsevents/speech/yellen20110601a.htm. 


\section{Figure 1}

\section{Insurance Company Holdings of Newly Issued Bonds}

This figure plots the fraction of newly issued bonds acquired by insurance companies between 2004:Q2-2007:Q2, sorted by NAIC risk categories (Panel A), promised yields and CDS spreads (Panel B). The fraction of holdings is computed with respect to the total dollar holdings by insurance companies, pension and mutual funds. We report equally-weighted averages across bonds. Bars correspond to 95\% confidence intervals (based on the standard deviation across individual bonds). In panel A, bonds are sorted by NAIC categories (except NAIC 6 which has few issues).In Panel B, investment grade bonds (NAIC 1 and 2) are sorted into quartiles of offering yield or CDS Spread.

\section{A. Holdings by NAIC categories}

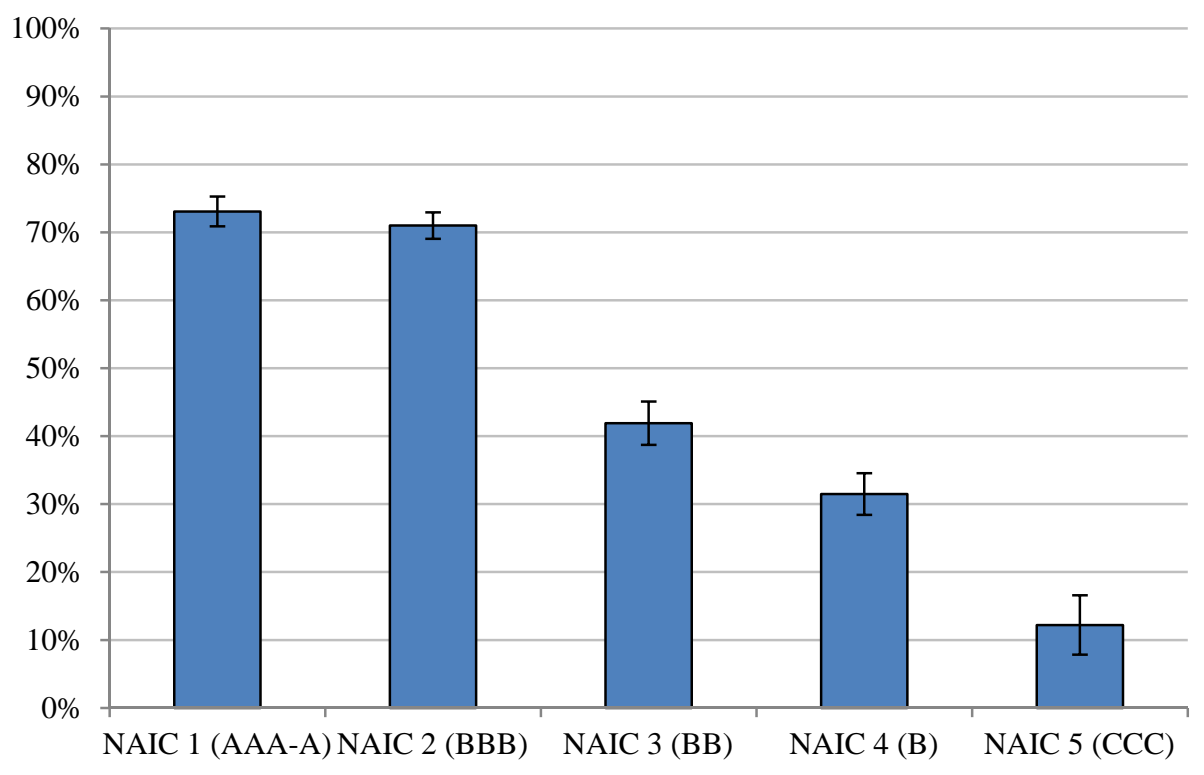

B. Holdings by yields and CDS spreads (investment grade bonds, NAIC 1 and 2)

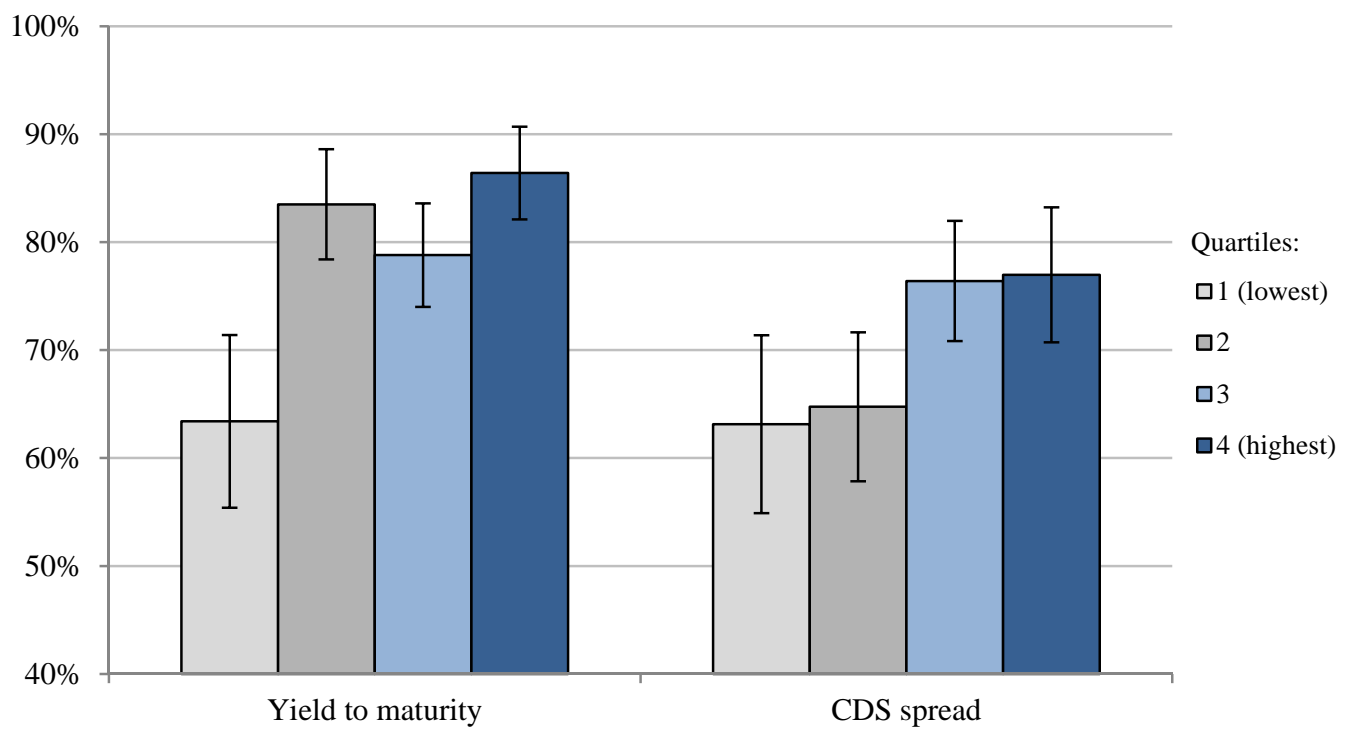


Figure 2

Newly Issued U.S. Corporate Bonds, 2004:Q3-2010:Q4

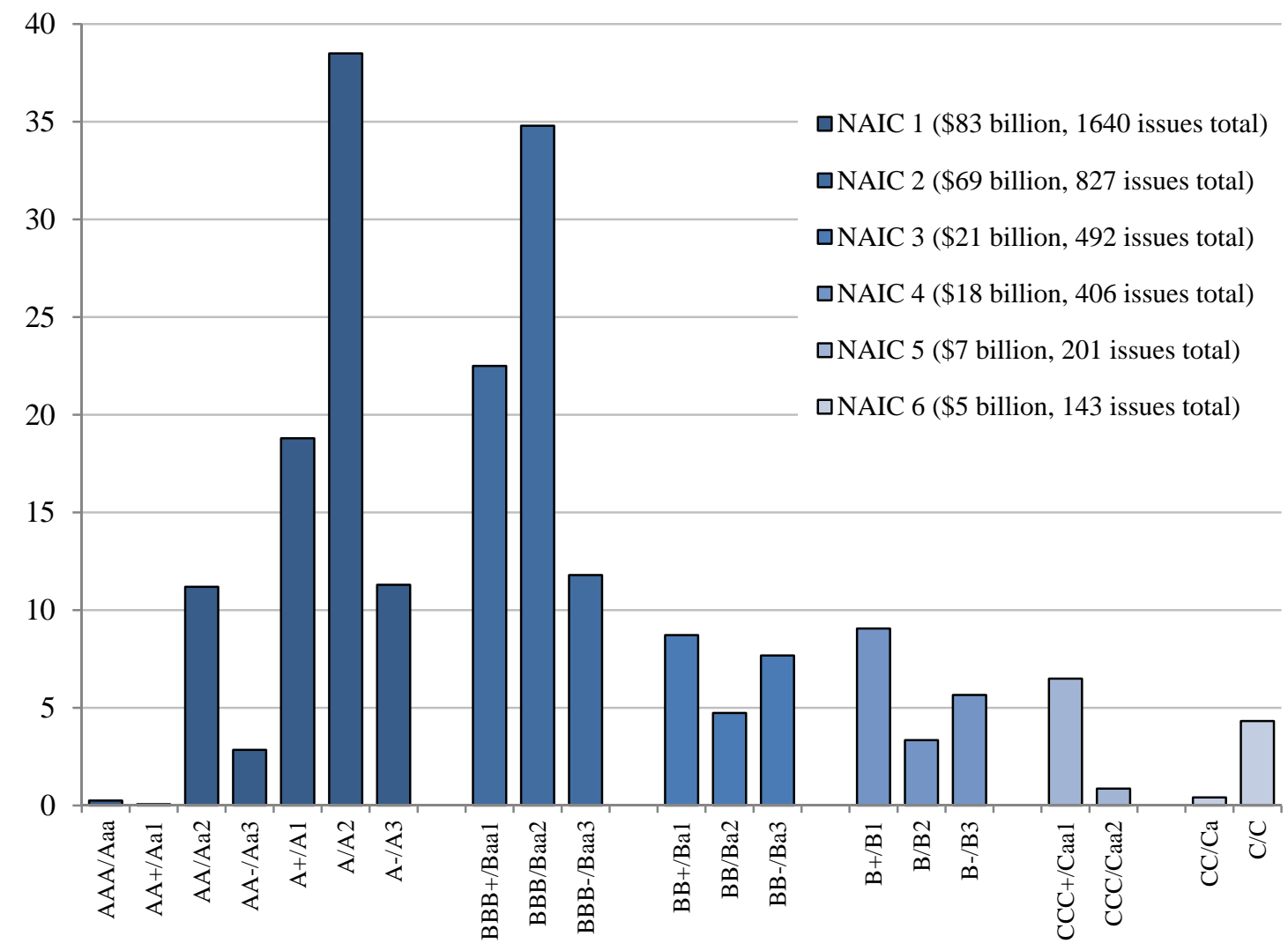




\section{Figure 3}

\section{Reaching for Yield}

This figure compares the value-weighted average yield on NAIC category 1 (rating A- up to AAA) corporate bonds acquired by insurance companies, mutual funds, and pension funds. Bars indicate $95 \%$ confidence intervals for the average, based on cross-sectional variation. For pension and mutual funds, we report differences as compared to insurance companies and standard errors (in brackets). ${ }^{* * *}, *$ indicate statistical significance at $1 \%$ and $10 \%$ level, respectively.

\section{A. Pre-crisis: 2004-2007:Q2}

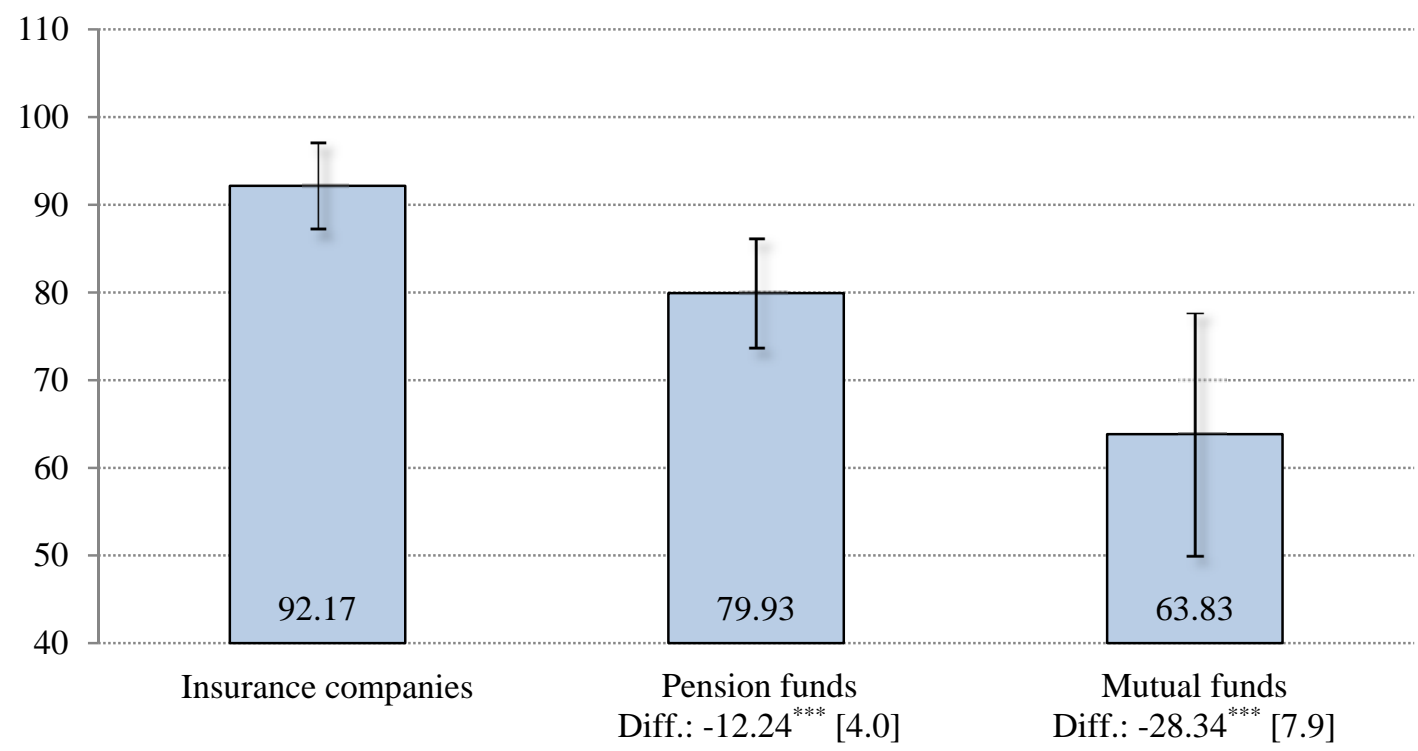

A. Crisis/Post-crisis: 2007:Q3-2010

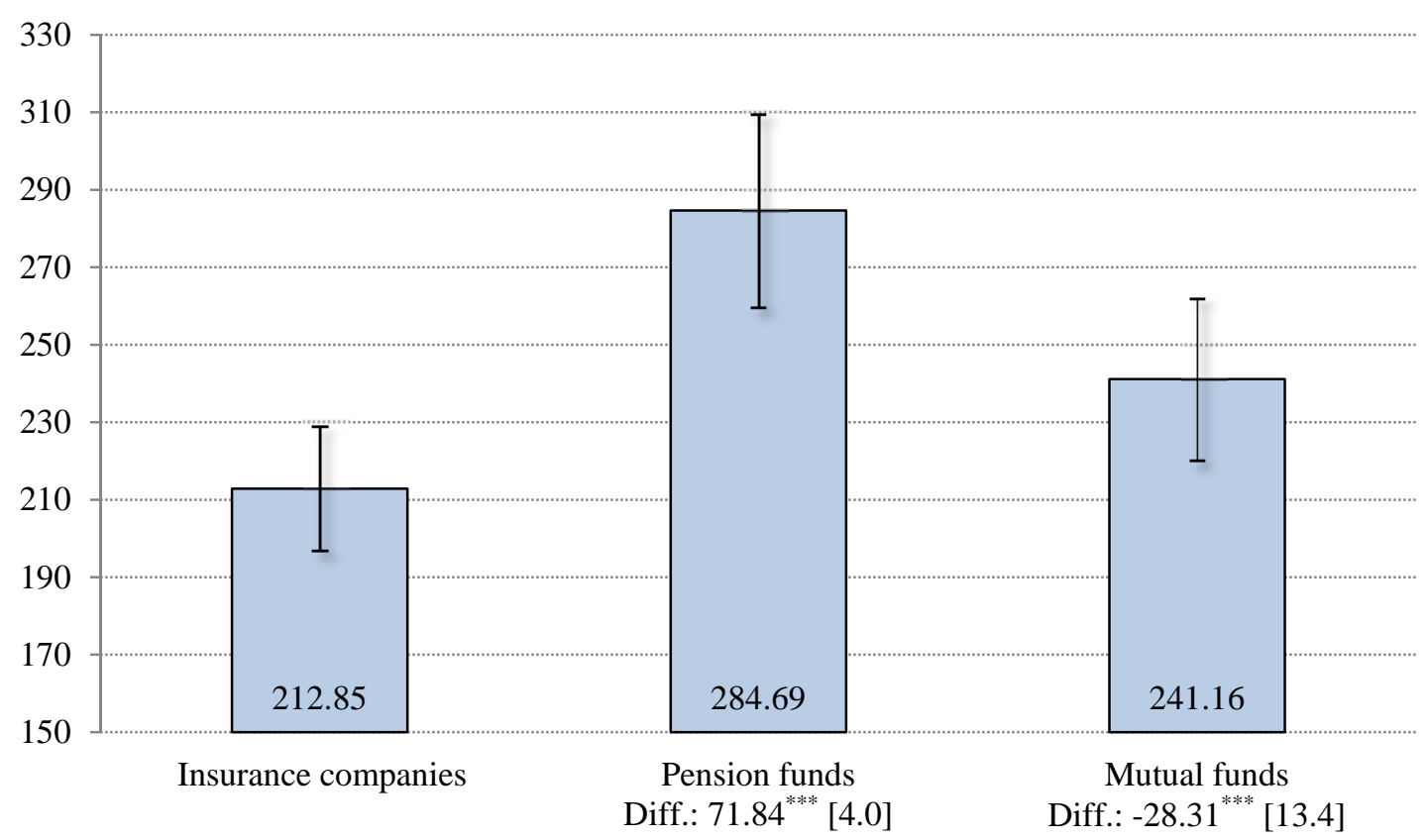


Figure 4

Relation between CDS Spread and Yield to Maturity at Bond Issuance

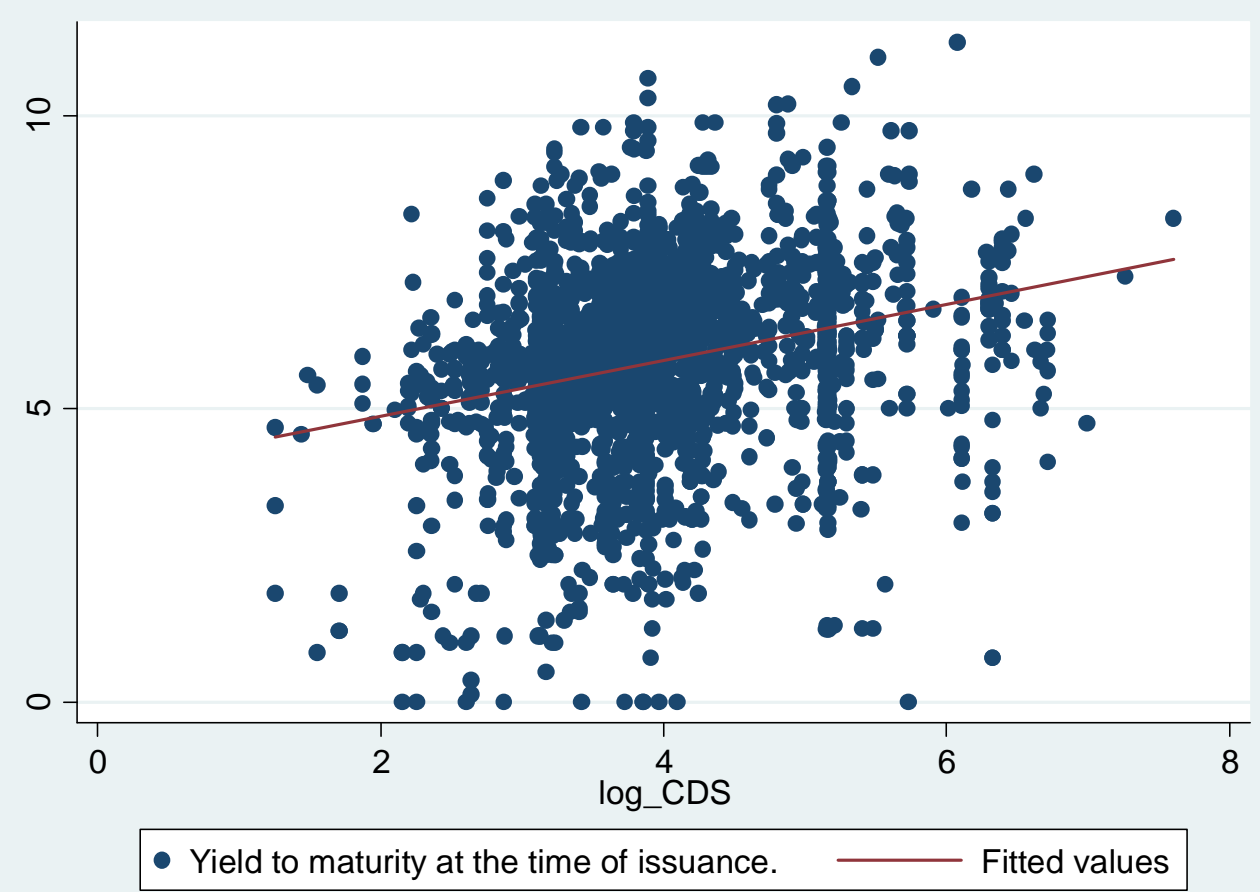


Figure 5

Insurance Companies' Capital Structure

The figure presents capital structure detail for U.S. insurance companies with more than $\$ 100$ million dollars of assets, for the 2010 fiscal year. The figure was compiled using Capital IQ.

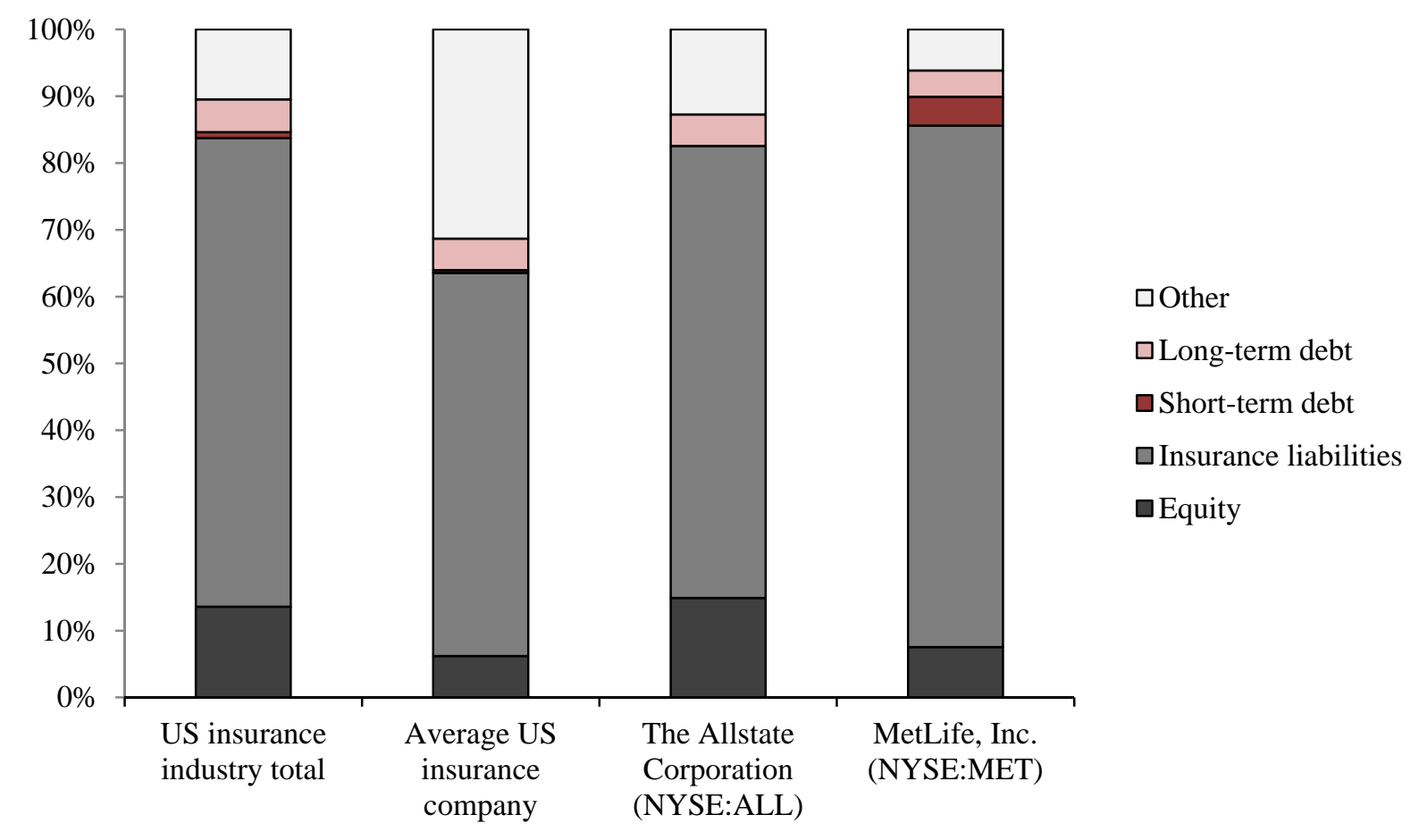




\section{Figure 6}

\section{Insurance Companies’ Stock Price Performance During Financial Crisis}

The figure presents stock returns for the period June 2008- February 2009 relative to their bond investment choices pre-crisis. Spread is the value-weighted average spread of NAIC1 (AAA-A) corporate bonds acquired in the 2004:Q3-2007:Q2 period. The figure was compiled using CRSP data on sock returns, holdings data from eMAXX and yield data from MergentFISD. The picture displays tickers for 16 largest firms in out sample based on 2004 assets; top-1 firm is AIG (NYSE: AIG) and top-16 is MBIA (NYSE: MBI).

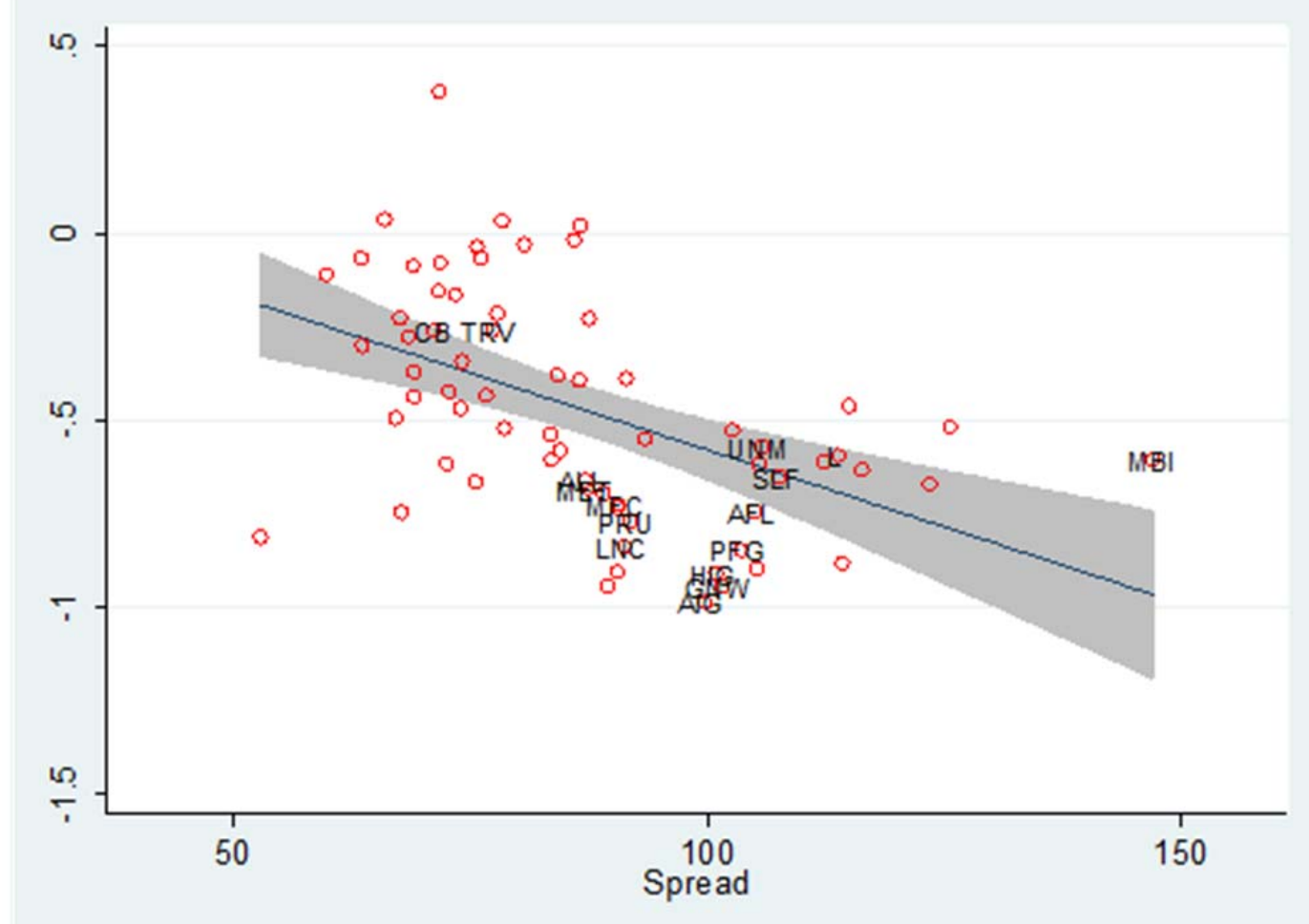


Figure 7

Reaching for Yield and Bond Issuance

The figure presents insurance companies' preference for high yielding bonds (bars, right axis) and the relative bond issuance of high CDS corporates (lines, left axis) within NAIC 2, i.e. ratings between BBB- and BBB+. The insurance preference is based on quarterly coefficients in Table VII. The time series of bond issuance reports the fraction of bonds issued by firms in the top half of issuers based on their CDS spread. The cutoff for CDS spreads is determined quarter-by-quarter.

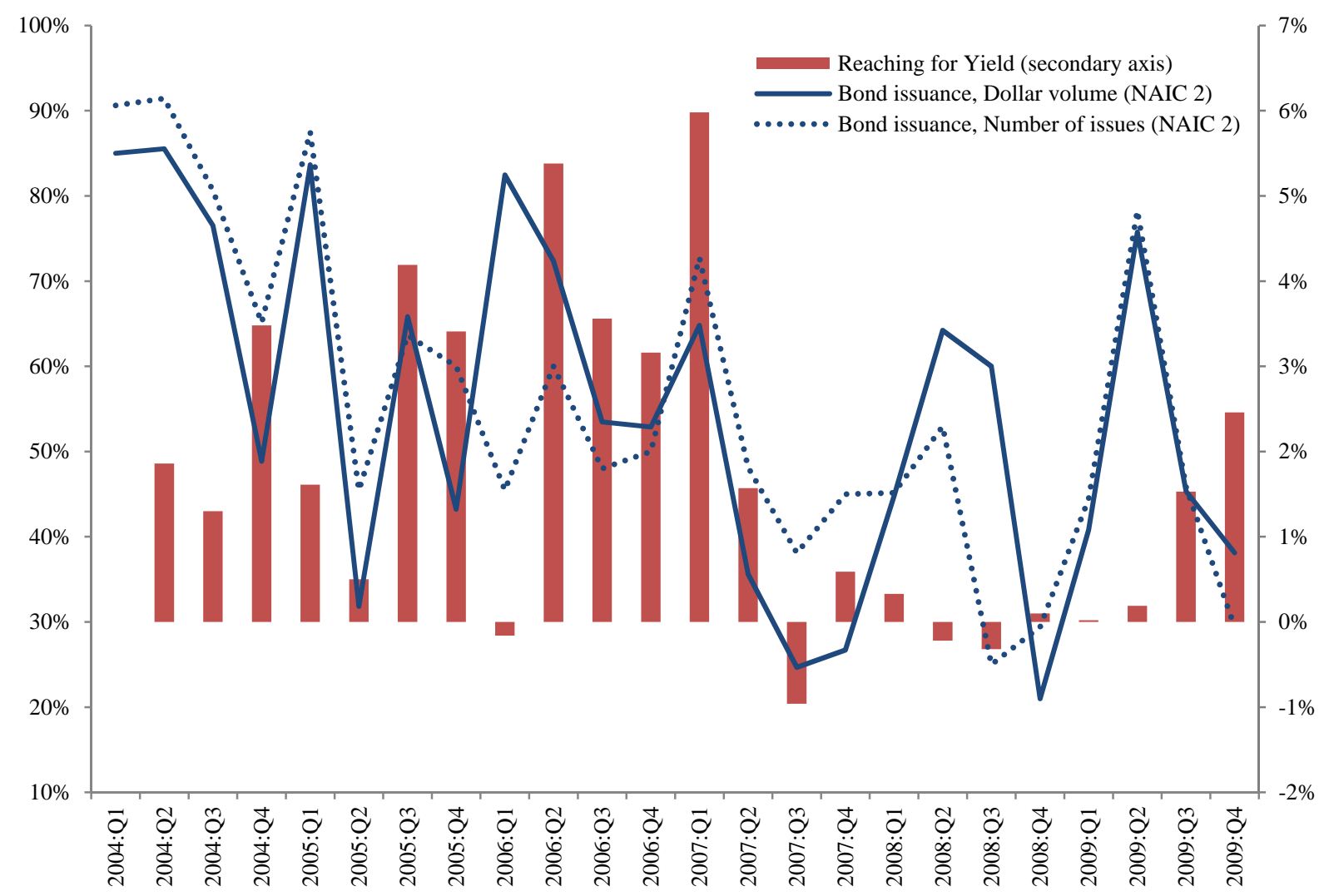


Table I

\section{Assets Distribution}

This figure is based on U.S. Flow of Funds Accounts. The numbers are in billions of U.S. dollars and correspond to amounts outstanding as of the end of 2010:Q4. Mutual funds include money market funds.

\begin{tabular}{|c|c|c|c|c|c|c|c|c|}
\hline & $\begin{array}{l}\text { Life insurance } \\
\text { companies }\end{array}$ & & $\begin{array}{l}\text { Property-casualty } \\
\text { insurance } \\
\text { companies }\end{array}$ & & Mutual funds & & $\begin{array}{l}\text { Private pension } \\
\text { funds }\end{array}$ & \\
\hline Total financial assets & $5,176.8$ & & $1,403.4$ & & $7,963.4$ & & $6,079.6$ & \\
\hline Treasury securities & 161.6 & $(3 \%)$ & 91.4 & $(7 \%)$ & 296.0 & $(4 \%)$ & 486.7 & $(8 \%)$ \\
\hline Corporate and foreign bonds & $2,022.7$ & $(39 \%)$ & 299.2 & $(21 \%)$ & $1,255.0$ & $(16 \%)$ & 482.5 & $(8 \%)$ \\
\hline Agency- and GSE-backed securities & 357.0 & $(7 \%)$ & 109.4 & $(8 \%)$ & 786.7 & $(10 \%)$ & 170.9 & $(3 \%)$ \\
\hline Mortgages & 318.0 & $(6 \%)$ & 4.1 & $(0 \%)$ & -- & & 15.1 & $(0 \%)$ \\
\hline Corporate equities & $1,423.2$ & $(27 \%)$ & 228.0 & $(16 \%)$ & $4,801.4$ & $(60 \%)$ & $1,983.3$ & $(33 \%)$ \\
\hline Mutual fund shares & 183.8 & $(4 \%)$ & 32.1 & $(2 \%)$ & -- & & 2,228.2 & (37\%) \\
\hline Total: & & $88 \%$ & & $81 \%$ & & $96 \%$ & & $88 \%$ \\
\hline
\end{tabular}


Table II

NAIC Risk-Based Capital Requirement

This summarizes National Association of Insurance Companies (NAIC) post-tax capital requirement factors (NAIC Risk-Based Capital Newsletter, 10/12/2001). Default rates are from Fitch Ratings Global Corporate Finance 2010 Transition and Default Study.

\begin{tabular}{|c|c|c|c|c|}
\hline NAIC categories & Credit ratings & & Capital charge & $\begin{array}{l}\text { 5-year cumulative default rates } \\
(1990-2010)\end{array}$ \\
\hline Federal government & & & Exempt & \\
\hline NAIC 1 (highest) & AAA, AA, A & Investment Grade & $0.3 \%$ & $0.00 \%, 0.09 \%, 0.69 \%$ \\
\hline NAIC 2 & $\mathrm{BBB}$ & Investment Grade & $0.96 \%$ & $2.62 \%$ \\
\hline NAIC 3 & $\mathrm{BB}$ & High Yield/Speculative Grade & $3.39 \%$ & $6.76 \%$ \\
\hline NAIC 4 & $\mathrm{~B}$ & High Yield/Speculative Grade & $7.38 \%$ & $8.99 \%$ \\
\hline NAIC 5 & CCC & High Yield/Speculative Grade & $16.96 \%$ & $34.38 \%$ \\
\hline NAIC 6 (lowest) & CC or below & High Yield/Speculative Grade & $19.50 \%$ & \\
\hline
\end{tabular}




\section{Table III}

\section{Bond and Issuer Characteristics across CDS Quartiles of Investment Grade Issuers}

This table presents the median of selected issuer and bond characteristics throughout the sample period, for investment grade issuers. The characteristics are at bond issuance. Each entry reports the median and, in parenthesis, the standard deviation of a characteristic. For credit ratings, the standard deviation is in notches (the difference between $\mathrm{A}$ and $\mathrm{A}$ - is one notch).

\begin{tabular}{cccccccc}
\hline Quartile & Bond yield & $\begin{array}{c}\text { Bond } \\
\text { maturity }\end{array}$ & $\begin{array}{c}\text { CDS } \\
\text { Spread }\end{array}$ & $\begin{array}{c}\text { Credit } \\
\text { rating }\end{array}$ & $\begin{array}{c}\text { Assets } \\
\text { (Billion USD) }\end{array}$ & $\begin{array}{c}\text { Book } \\
\text { leverage }\end{array}$ & $\begin{array}{c}\text { Return on } \\
\text { assets }\end{array}$ \\
\hline \multirow{2}{*}{1} & 5.69 & 9.8 & 16.9 & A & 25.7 & 0.24 & 0.067 \\
& $(1.72)$ & $(13.2)$ & $(14.1)$ & $(2.3)$ & $(120)$ & $(0.13)$ & $(0.047)$ \\
2 & 5.80 & 9.0 & 43.5 & A & 21.5 & 0.28 & 0.053 \\
& $(1.74)$ & $(11.5)$ & $(18.8)$ & $(1.8)$ & $(125)$ & $(0.16)$ & $(0.052)$ \\
3 & 6.04 & 10.0 & 57.8 & A- & 15.4 & 0.30 & 0.044 \\
& $(1.57)$ & $(12.1)$ & $(32.6)$ & $(1.8)$ & $(167)$ & $(0.16)$ & $(0.061)$ \\
4 & 6.10 & 9.2 & 156.8 & A- & 13.7 & 0.31 & 0.022 \\
& $(1.60)$ & $(9.6)$ & $(287.5)$ & $(1.8)$ & $(170)$ & $(0.20)$ & $(0.085)$ \\
\hline
\end{tabular}


Table IV

\section{Reaching for Yield: Yield to Maturity}

We look at the investment decision immediately following bond issuance. With the exception of specification (4), the sample is composed of investment grade issues (NAIC Categories 1 and 2). Specification (4) corresponds to non-investment/speculative grade. Treasury spread is the yield difference between a bond and a maturity-matched treasury bond. Duration is computed using bond information from Mergent FISD. Credit ratings fixed effects are AAA, AA+, AA, AA-, etc.. Standard errors clustered by issuer and are reported in brackets. ***, **, * indicate statistical significance at $1 \%, 5 \%$ and $10 \%$ level, respectively.

\begin{tabular}{|c|c|c|c|c|c|c|c|}
\hline \multirow[t]{4}{*}{ Dependent variable: } & \multicolumn{7}{|c|}{$\begin{array}{l}\text { Insurance companies' holding as a fraction of insurance, mutual and pension funds } \\
\text { holding amount }\end{array}$} \\
\hline & \multicolumn{4}{|c|}{$\begin{array}{c}\text { Benchmark } \\
(2004: Q 3-2007: Q 2) \\
\end{array}$} & \multirow{2}{*}{\multicolumn{3}{|c|}{$\begin{array}{c}\text { Crisis } \\
(2007: Q 3-2010: Q 4) \\
\text { Investment grade } \\
\end{array}$}} \\
\hline & \multicolumn{3}{|c|}{ Investment grade } & \multirow{2}{*}{$\frac{\text { Speculative }}{(4)}$} & & & \\
\hline & $(1)$ & $(2)$ & $(3)$ & & $(5)$ & $(6)$ & $(7)$ \\
\hline Treasury spread & $\begin{array}{l}0.055^{*} \\
{[0.029]}\end{array}$ & $\begin{array}{l}0.067 * * * \\
{[0.023]}\end{array}$ & $\begin{array}{l}0.047 * * \\
{[0.018]}\end{array}$ & $\begin{array}{l}0.018 \\
{[0.019]}\end{array}$ & $\begin{array}{l}-0.028 \\
{[0.018]}\end{array}$ & $\begin{array}{l}-0.042^{* *} \\
{[0.017]}\end{array}$ & $\begin{array}{l}-0.038 * * \\
{[0.017]}\end{array}$ \\
\hline NAIC Category 2 (BBB+, BBB, BBB-) & $\begin{array}{l}-0.003 \\
{[0.050]}\end{array}$ & $\begin{array}{l}-0.010 \\
{[0.022]}\end{array}$ & -- & -- & $\begin{array}{l}-0.049 \\
{[0.062]}\end{array}$ & $\begin{array}{l}0.014 \\
{[0.036]}\end{array}$ & -- \\
\hline Duration (years) & -- & $\begin{array}{l}0.009 * * \\
{[0.003]}\end{array}$ & $\begin{array}{l}0.008^{* *} \\
{[0.003]}\end{array}$ & $\begin{array}{l}0.007 \\
{[0.010]}\end{array}$ & -- & $\begin{array}{l}0.000 \\
{[0.005]}\end{array}$ & $\begin{array}{l}0.001 \\
{[0.005]}\end{array}$ \\
\hline Offering amount & -- & $\begin{array}{l}-0.025^{* * *} \\
{[0.003]}\end{array}$ & $\begin{array}{l}-0.021 * * * \\
{[0.004]}\end{array}$ & $\begin{array}{l}-0.072 * * * \\
{[0.012]}\end{array}$ & -- & $\begin{array}{l}-0.056 * * * \\
{[0.006]}\end{array}$ & $\begin{array}{l}-0.058 * * * \\
{[0.007]}\end{array}$ \\
\hline $\begin{array}{l}\text { Fixed effects: } \\
\text { Rating * Year (interacted) }\end{array}$ & No & No & Yes & Yes & No & No & Yes \\
\hline Observations & 589 & 589 & 589 & 188 & 325 & 325 & 325 \\
\hline Clusters (issuers) & 141 & 141 & 138 & 78 & 93 & 93 & 91 \\
\hline$R$-squared & 0.03 & 0.17 & 0.31 & 0.30 & 0.06 & 0.26 & 0.32 \\
\hline
\end{tabular}




\section{Table V}

\section{Reaching for Yield: CDS Spread}

We look at the investment decision immediately following bond issuance. With the exception of specification (4), the sample is composed of investment grade issues (NAIC Categories 1 and 2). Specification (4) corresponds to non-investment/speculative grade. Duration is computed using bond information from MergentFISD. Credit ratings fixed effects are AAA, AA+, AA, AA-, etc.. Standard errors clustered by issuer and are reported in brackets. ***, **, * indicate statistical significance at $1 \%, 5 \%$ and $10 \%$ level, respectively.

\begin{tabular}{|c|c|c|c|c|c|c|c|}
\hline \multirow[t]{4}{*}{ Dependent variable: } & \multicolumn{7}{|c|}{$\begin{array}{c}\text { Insurance companies’ holding as a fraction of insurance, mutual and pension funds } \\
\text { holding amount }\end{array}$} \\
\hline & \multicolumn{4}{|c|}{$\begin{array}{c}\text { Benchmark } \\
(2004: Q 3-2007: Q 2) \\
\end{array}$} & \multirow{2}{*}{\multicolumn{3}{|c|}{$\begin{array}{c}\text { Crisis } \\
\text { (2007:Q3-2010:Q4) } \\
\text { Investment grade }\end{array}$}} \\
\hline & \multicolumn{3}{|c|}{ Investment grade } & \multirow{2}{*}{$\begin{array}{l}\text { Speculative } \\
(4)\end{array}$} & & & \\
\hline & (1) & $(2)$ & (3) & & (5) & (6) & (7) \\
\hline CDS spread & $\begin{array}{l}0.060^{* *} \\
{[0.028]}\end{array}$ & $\begin{array}{l}0.049 * \\
{[0.030]}\end{array}$ & $\begin{array}{l}0.003 \\
{[0.002]}\end{array}$ & $\begin{array}{l}-0.038 \\
{[0.045]}\end{array}$ & $\begin{array}{l}-0.058 \\
{[0.054]}\end{array}$ & $\begin{array}{l}-0.110^{* * *} \\
{[0.021]}\end{array}$ & $\begin{array}{l}-0.113^{* * *} \\
{[0.024]}\end{array}$ \\
\hline NAIC Category 2 (BBB+, BBB, BBB-) & $\begin{array}{l}-0.057 \\
{[0.050]}\end{array}$ & $\begin{array}{l}-0.045 \\
{[0.039]}\end{array}$ & -- & -- & $\begin{array}{l}-0.052 \\
{[0.061]}\end{array}$ & $\begin{array}{l}0.014 \\
{[0.032]}\end{array}$ & -- \\
\hline Duration (years) & -- & $\begin{array}{l}0.009^{* *} \\
{[0.004]}\end{array}$ & $\begin{array}{l}0.005^{* * *} \\
{[0.002]}\end{array}$ & $\begin{array}{l}0.003 \\
{[0.007]}\end{array}$ & -- & $\begin{array}{l}0.002 \\
{[0.005]}\end{array}$ & $\begin{array}{l}0.004 \\
{[0.004]}\end{array}$ \\
\hline Offering amount & -- & $\begin{array}{l}-0.019 * * * \\
{[0.06]}\end{array}$ & $\begin{array}{l}0.012 \\
{[0.023]}\end{array}$ & $\begin{array}{l}-0.046^{* *} \\
{[0.018]}\end{array}$ & -- & $\begin{array}{l}-0.068 * * * \\
{[0.008]}\end{array}$ & $\begin{array}{l}-0.075^{* * *} \\
{[0.007]}\end{array}$ \\
\hline $\begin{array}{l}\text { Fixed effects: } \\
\text { Rating * Year (interacted) }\end{array}$ & No & No & Yes & Yes & No & No & Yes \\
\hline Observations & 686 & 547 & 547 & 188 & 395 & 325 & 325 \\
\hline Clusters (issuers) & 139 & 126 & 123 & 78 & 106 & 93 & 91 \\
\hline$R$-squared & 0.03 & 0.13 & 0.14 & 0.35 & 0.05 & 0.31 & 0.438 \\
\hline
\end{tabular}




\section{Table VI}

\section{Reaching for Yield: Secondary Market (Trades)}

This table reports results from panel regressions of secondary market activity of insurance companies in investment grade corporate bonds. The dependent variable is the log quarterly change in the value of all insurance companies' holdings of a bond (maturing bonds are excluded). Observations where the dependent variable is above 1 are excluded. The sample is constrained to investment grade issues (NAIC Categories 1 and 2). Duration is computed using bond information from MergentFISD. Trading volume is the log of the value of transactions in TRACE for a given bond, divided by total par value outstanding, lagged one quarter. Number of trades is the log of the number of investors reporting a changed position in the previous quarter in eMAXX. Standard errors clustered by issuer and are reported in brackets. ${ }^{* *},{ }^{* *}, *$ indicate statistical significance at $1 \%, 5 \%$ and $10 \%$ level, respectively.

\begin{tabular}{|c|c|c|c|}
\hline \multirow[t]{3}{*}{ Dependent variable: } & \multicolumn{3}{|c|}{$\begin{array}{l}\text { Log change in value of insurance companies' total } \\
\text { holdings since previous quarter }\end{array}$} \\
\hline & \multicolumn{2}{|c|}{$\begin{array}{c}\text { Benchmark } \\
\text { (2004:Q3-2007:Q2) }\end{array}$} & \multirow{2}{*}{$\begin{array}{c}\text { Crisis } \\
\text { (2007:Q3-2010:Q4) } \\
\text { (3) }\end{array}$} \\
\hline & $(1)$ & $(2)$ & \\
\hline Yield to maturity & $\begin{array}{l}0.036^{* * *} \\
{[0.012]}\end{array}$ & $\begin{array}{l}0.039 * * * \\
{[0.013]}\end{array}$ & $\begin{array}{l}0.004 \\
{[0.004]}\end{array}$ \\
\hline NAIC Category 2 (BBB+, BBB, BBB-) & $\begin{array}{l}-0.009 * \\
{[0.005]}\end{array}$ & $\begin{array}{l}-0.014^{* *} \\
{[0.005]}\end{array}$ & $\begin{array}{l}-0.107 \\
{[0.068]}\end{array}$ \\
\hline Duration & $\begin{array}{l}-0.003 \\
{[0.002]}\end{array}$ & $\begin{array}{l}-0.004^{*} \\
{[0.002]}\end{array}$ & $\begin{array}{l}0.003^{* *} \\
{[0.001]}\end{array}$ \\
\hline Trading volume & -- & $\begin{array}{l}0.004 \\
{[0.004]}\end{array}$ & $\begin{array}{l}-0.002 \\
{[0.005]}\end{array}$ \\
\hline Number of trades & -- & $\begin{array}{l}-0.005 \\
{[0.005]}\end{array}$ & $\begin{array}{l}0.006 \\
{[0.005]}\end{array}$ \\
\hline $\begin{array}{l}\text { Fixed effects: } \\
\text { Firm-quarter }\end{array}$ & Yes & Yes & Yes \\
\hline Observations & 2,040 & 1,865 & 1,772 \\
\hline Clusters (issuers) & 36 & 33 & 33 \\
\hline$R$-squared & 0.25 & 0.28 & 0.38 \\
\hline
\end{tabular}




\section{Table VII}

\section{Reaching for Yield: Time Series Variation}

This table reports results from panel regressions of secondary market activity of insurance companies in investment grade corporate bonds. The dependent variable is the log quarterly change in the value of all insurance companies' holdings of a bond (maturing bonds are excluded). The sample is constrained to investment grade issues (NAIC Categories 1 and 2). The coefficient on yield is allowed to vary by quarter. Standard errors clustered by issuer and are reported in a separate column. $* * *, * *, *$ indicate statistical significance at $1 \%, 5 \%$ and $10 \%$ level, respectively.

\begin{tabular}{|c|c|c|c|}
\hline \multirow{2}{*}{\multicolumn{2}{|c|}{ Dependent variable: }} & \multicolumn{2}{|c|}{$\begin{array}{l}\text { Log change in value of insurance companies' } \\
\text { total holdings since previous quarter }\end{array}$} \\
\hline & & Coeff. & Std. error \\
\hline \multicolumn{4}{|c|}{ Interaction terms (yield*quarter): } \\
\hline & 2004:Q2 & 0.0186 & [0.0129] \\
\hline & 2004:Q3 & 0.0130 & {$[0.0117]$} \\
\hline & 2004:Q4 & $0.0348 * * *$ & {$[0.0100]$} \\
\hline & 2005:Q1 & 0.0161 & [0.0107] \\
\hline & 2005:Q2 & 0.0050 & [0.0101] \\
\hline & 2005:Q3 & $0.0419 * * *$ & [0.0083] \\
\hline & 2005:Q4 & $0.0341^{* * *}$ & {$[0.0115]$} \\
\hline & 2006:Q1 & -0.0016 & [0.0192] \\
\hline & 2006:Q2 & $0.0538 * * *$ & {$[0.0176]$} \\
\hline & 2006:Q3 & $0.0356^{*}$ & {$[0.0196]$} \\
\hline & 2006:Q4 & $0.0316^{* *}$ & [0.0155] \\
\hline & 2007:Q1 & $0.0598 * * *$ & [0.0152] \\
\hline & 2007:Q2 & 0.0157 & {$[0.0207]$} \\
\hline \multirow{13}{*}{ 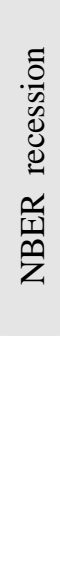 } & 2007:Q3 & -0.0096 & [0.0138] \\
\hline & 2007:Q4 & 0.0059 & [0.0051] \\
\hline & 2008:Q1 & 0.0033 & [0.0037] \\
\hline & 2008:Q2 & -0.0022 & {$[0.0064]$} \\
\hline & 2008:Q3 & -0.0032 & {$[0.0034]$} \\
\hline & 2008:Q4 & 0.0010 & [0.0013] \\
\hline & 2009:Q1 & 0.0002 & {$[0.0014]$} \\
\hline & 2009:Q2 & 0.0019 & [0.0067] \\
\hline & 2009:Q3 & $0.0153^{* *}$ & [0.0078] \\
\hline & 2009:Q4 & $0.0246^{* * *}$ & [0.0074] \\
\hline & 2010:Q1 & 0.0092 & {$[0.0088]$} \\
\hline & 2010:Q2 & 0.0139 & [0.0092] \\
\hline & 2010:Q3 & 0.0059 & {$[0.0099]$} \\
\hline \multicolumn{2}{|c|}{ Firm-quarter fixed effects: } & Yes & \\
\hline & Observations & 7,948 & \\
\hline & $R$-squared & 0.27 & \\
\hline
\end{tabular}




\section{Table VIII \\ Bond Performance}

This table examines bonds secondary market performance for 2004-2007. The test focuses on newly issued investment grade bonds. The dependent variable is monthly excess return (returns in excess of the risk-free rate) measured in basis points. Returns are constructed using prices from non-cancelled transactions reported in TRACE. Monthly returns are computed using median trade price at the last day of the month and factor in bond coupons. For a given month, the sample includes bonds acquired within 1-year window. We report equally-weighted excess returns for the portfolio with the highest (above the median) and lowest (below the median) insurance holdings measured at issuance. The risk-free rate and market return are from Ken French's website. The default spread is the difference in returns between investment grade and high yield corporate bonds (the Lehman/Barclays index), and the term spread is the difference in returns between the five year treasury bond and the three month treasury bill. Liquidity is the return factor of Pastor and Stambaugh (2003). ${ }^{* * *}, * * * *$ indicate statistical significance at 1\%, 5\% and $10 \%$ level, respectively.

\begin{tabular}{|c|c|c|c|c|c|c|}
\hline \multirow[t]{2}{*}{ Bond portfolio } & \multicolumn{3}{|c|}{$\begin{array}{c}\text { High } \\
\text { insurance holdings }\end{array}$} & \multicolumn{3}{|c|}{$\begin{array}{c}\text { Low } \\
\text { insurance holdings }\end{array}$} \\
\hline & $(1)$ & $(2)$ & (3) & (4) & (5) & (6) \\
\hline Intercept (“Alpha”) & $\begin{array}{l}-27.9 \\
{[22.8]}\end{array}$ & $\begin{array}{l}-49.2 * * \\
{[21.9]}\end{array}$ & $\begin{array}{l}-12.7 \\
{[27.6]}\end{array}$ & $\begin{array}{l}2.8 \\
{[5.2]}\end{array}$ & $\begin{array}{l}-11.8 \\
{[15.8]}\end{array}$ & $\begin{array}{l}-1.8 \\
{[14.8]}\end{array}$ \\
\hline Stock market excess return & $\begin{array}{l}0.17 * * \\
{[0.08]}\end{array}$ & $\begin{array}{l}0.21 * * * \\
{[0.08]}\end{array}$ & $\begin{array}{l}0.17 * * \\
{[0.07]}\end{array}$ & $\begin{array}{l}0.03 \\
{[0.05]}\end{array}$ & $\begin{array}{l}0.08^{*} \\
{[0.04]}\end{array}$ & $\begin{array}{l}0.03 \\
{[0.05]}\end{array}$ \\
\hline Default premium & -- & $\begin{array}{l}0.51^{*} \\
{[0.30]}\end{array}$ & -- & -- & $\begin{array}{l}0.12^{* *} \\
{[0.06]}\end{array}$ & -- \\
\hline Term spread & -- & $\begin{array}{l}0.36^{* * *} \\
{[0.08]}\end{array}$ & -- & -- & $\begin{array}{l}0.35^{* * * *} \\
{[0.04]}\end{array}$ & -- \\
\hline Liquidity factor & -- & -- & $\begin{array}{l}0.14 \\
{[0.09]}\end{array}$ & -- & -- & $\begin{array}{l}0.04 \\
{[0.06]}\end{array}$ \\
\hline $\begin{array}{l}\text { Observations } \\
R \text {-squared }\end{array}$ & 48 & 48 & 48 & $\begin{array}{l}48 \\
0.01\end{array}$ & $\begin{array}{l}48 \\
0.67\end{array}$ & $\begin{array}{l}48 \\
0.02\end{array}$ \\
\hline $\begin{array}{l}\text { Mean excess return } \\
\text { Std. dev. }\end{array}$ & $\begin{array}{l}-17.4 \\
156.7\end{array}$ & & & $\begin{array}{l}4.5 \\
85.6\end{array}$ & & \\
\hline
\end{tabular}




\section{Table IX}

\section{Governance and Reaching for Yield}

This table reports results from cross-sectional regressions of purchases of insurance companies of NAIC 1 and 2 (i.e., investment grade) corporate bonds. We look at purchases at bond issue for the period 20034-2007. The dependent variable, Treasury spread, is the difference between the average promised yield-to-maturity on bonds acquired by a given insurance company and a maturity-matched treasury bond in each year. Regulatory capital surplus is capital surplus normalized by assets. Block-holder ownership measures the fraction of outstanding shares held by block-holders. Public firm is a dummy indicating whether the firm is publically traded. Leverage is the ratio of liabilities to equity, and is capped at 20. Size is the log of assets (book value). Robust standard errors, clustered by firm, are reported in brackets. ${ }^{* *},{ }^{* *}, *$ indicate statistical significance at $1 \%, 5 \%$ and $10 \%$ level, respectively.

\begin{tabular}{|c|c|c|c|c|c|}
\hline \multirow[t]{2}{*}{ Dependent variable: } & \multicolumn{5}{|c|}{ Treasury spread } \\
\hline & (1) & (2) & (3) & (4) & (5) \\
\hline \multicolumn{6}{|c|}{ Insurance companies characteristics: } \\
\hline Regulatory capital surplus & $\begin{array}{l}-0.512 * * * \\
{[0.118]}\end{array}$ & $\begin{array}{l}-0.394 * * * \\
{[0.130]}\end{array}$ & -- & -- & $\begin{array}{l}-0.683^{*} \\
{[0.373]}\end{array}$ \\
\hline Block-holder ownership & -- & - & $\begin{array}{l}-0.348 * * * \\
{[0.120]}\end{array}$ & $\begin{array}{l}-0.328 * * * \\
{[0.119]}\end{array}$ & $\begin{array}{l}-0.286^{*} \\
{[0.147]}\end{array}$ \\
\hline Public firm & -- & $\begin{array}{l}4.83 \\
{[3.75]}\end{array}$ & -- & -- & -- \\
\hline Leverage & -- & $\begin{array}{l}-0.061 \\
{[0.129]}\end{array}$ & -- & $\begin{array}{l}0.059 \\
{[0.665]}\end{array}$ & $\begin{array}{l}-0.443 \\
{[0.846]}\end{array}$ \\
\hline Size & -- & $\begin{array}{l}1.43^{* *} \\
{[0.731]}\end{array}$ & -- & $\begin{array}{l}2.21^{*} \\
{[1.32]}\end{array}$ & $\begin{array}{l}1.19 \\
{[1.50]}\end{array}$ \\
\hline Observations & 578 & 572 & 286 & 286 & 286 \\
\hline$R$-squared & 0.13 & 0.17 & 0.08 & 0.15 & 0.20 \\
\hline
\end{tabular}




\section{Table X}

\section{Reaching for Yield and Insurance Companies’ Performance}

This table reports results from regressing insurance companies’ stock returns during the financial crisis (June 2008 to February 2009) on their pre-crisis portfolio choices. Each observation in the analysis corresponds to a different insurance firm (this is a pure cross-section). In columns (1), (2), (5) and (6), the dependent variable is the raw return; in columns (3) and (4), the dependent variable is the excess return calculated using a market model with betas estimated based on 2002-2010 data. NAIC 1 corporate bonds issued during the period 2004:Q3-2007:Q2. Average Treasury Spread and Average Offering Spread are the value-weighted average spreads for bonds acquired by a given insurance company at their issuance. TARP recipient indicates three insurance companies that received support under the Federal Reserves Troubled Asset Relief Program in the fall of 2008. Stock Beta and Stock Volatility are estimated using daily data for 2001-2011 period. Robust standard errors are reported in brackets. ***, **, * indicate statistical significance at $1 \%, 5 \%$ and $10 \%$ level, respectively.

\begin{tabular}{|c|c|c|c|c|c|c|}
\hline \multirow[t]{2}{*}{ Dependent variable: } & \multicolumn{2}{|c|}{ Return } & \multicolumn{2}{|c|}{ Excess return } & \multicolumn{2}{|c|}{ Return } \\
\hline & (1) & (2) & (3) & (4) & (5) & (6) \\
\hline \multicolumn{7}{|l|}{ Insurance companies: } \\
\hline Average Treasury Spread & $\begin{array}{l}-0.824 * * * \\
{[0.191]}\end{array}$ & -- & $\begin{array}{l}-0.359 * \\
{[0.188]}\end{array}$ & -- & $\begin{array}{l}-0.399 * * \\
{[0.184]}\end{array}$ & -- \\
\hline Average Offering Spread & -- & $\begin{array}{l}-0.423^{* * *} \\
{[0.088]}\end{array}$ & -- & $\begin{array}{l}-0.222 * * \\
{[0.100]}\end{array}$ & -- & $\begin{array}{l}-0.183^{*} \\
{[0.099]}\end{array}$ \\
\hline TARP recipient & -- & -- & -- & -- & $\begin{array}{l}-0.058 \\
{[0.068]}\end{array}$ & $\begin{array}{l}-0.059 \\
{[0.073]}\end{array}$ \\
\hline Stock Beta & -- & -- & -- & -- & $\begin{array}{l}-0.114 \\
{[0.070]}\end{array}$ & $\begin{array}{l}-0.146^{*} \\
{[0.075]}\end{array}$ \\
\hline Stock Volatility & -- & -- & -- & -- & $\begin{array}{l}-4.76^{* * *} \\
{[1.435]}\end{array}$ & $\begin{array}{l}-4.50 * * * \\
{[1.601]}\end{array}$ \\
\hline Observations & 67 & 67 & 67 & 67 & 67 & 67 \\
\hline$R$-squared & 0.25 & 0.21 & 0.06 & 0.08 & 0.52 & 0.51 \\
\hline
\end{tabular}


APPENDIX 
In the empirical tests, we aim to examine (a) the existence of reaching-for-yield, and (b) how it depends on macroeconomic conditions.

A portfolio manager that is reaching-for-yield will always pick the highest yielding security for a given risk benchmark (assuming there are no costs to doing this.) For an investor whose risk is evaluated exclusively using credit ratings, bonds with higher yield within a rating appear more attractive, regardless of their actual risk. In the extreme, a manager would want to allocate a whole portfolio to the single highest-yielding asset. However, for a forward-looking manager and in the presence of ratings changes, the allocation decision is more intricate. In this dynamic setting, the portfolio decision balances expected yield against the risk of being downgraded (for insurance companies, this raises future capital requirements). To fix ideas, we formalize the investment decisions of a portfolio manager in a simple two-period, two-asset model:

Consider a portfolio manager deciding to allocate $\$ 1$ between two securities. The manager invests an amount $\alpha_{i}$ in security $i$. The manager works for a principal who dislikes risk; this could be a regulator or an ultimate investor who has delegated the portfolio decision. The principal and manager agree that the promised return of asset $i$ is $\bar{r}_{l}$. Securities are assigned ratings, which can be $A$ or $B$, where $A$ reflects a safer asset, by a third party. Both securities have an $A$ rating, but asset 1 has a lower yield: $\overline{r_{1}}<\overline{r_{2}}$.

Case 1: Consider the case where the principal imposes no penalties and where the manager gets a linear contract based on returns. In this scenario, the manager maximizes her expected utility $U(x)=\pi+$ $\tau E[x]$ for the linear sharing rule $\{\pi, \tau\}$. As long as $\tau$ is positive, it is optimal for the manager to simply maximize $E[x]$ :

$$
\max _{\alpha \in[0,1]} \sum_{i} \alpha_{i} \bar{r}_{l}, \text { s.t. } \sum_{i} \alpha_{i}=1
$$

The optimum is a corner solution, where the manager puts the whole portfolio in the security offering the highest return (second security). This manager favors high yielding securities even if they are riskier, because there is no cost associated with it. 
Case 2: We now allow for capital requirements or, more broadly, penalties based on ratings. Penalties are $c_{A}$ and $c_{B}=c_{A}+\Delta>c_{A}$ for assets rated $A$ and $B$, respectively. Penalties are assessed in period two at which point the initial rating may have changed (recall, both assets are assigned rating $\mathrm{A}$ at the start). The probability of a downgrade from $A$ to $B$ is $p^{-} \in[0,1]$, so that the expected capital requirement for the (initial) $A$ securities is $\left(1-p_{i}^{-}\right) c_{A}+p_{i}^{-} c_{B}=c_{A}+p_{i}^{-} \Delta$. We assume that the higher yielding security is more likely to be downgraded, so that $p_{1}^{-}<p_{2}^{-}$. In this setting the investor solves the following problem:

$$
\begin{gathered}
\max _{\alpha \in[0,1]} \sum_{i} \alpha_{i} \bar{r}_{l}-\alpha_{1}\left[c_{A}+p_{1}^{-} \Delta\right]-\alpha_{2}\left[c_{A}+p_{2}^{-} \Delta\right], \text { s.t. } \sum_{i} \alpha_{i}=1 \\
\text { or } \\
\max _{\alpha \in[0,1]} \sum_{i} \alpha_{i}\left[\bar{r}_{l}-p_{i}^{-} \Delta\right], \text { s.t. } \sum_{i} \alpha_{i}=1
\end{gathered}
$$

Due to the linearity of this problem, the manager will again concentrate his portfolio in a single asset. From the first order conditions we conclude that asset 1 is preferred to asset 2 (i.e., the marginal utility of investing in asset 1 is higher) if $\overline{r_{2}}-\overline{r_{1}} \geq \Delta\left(p_{2}^{-}-p_{1}^{-}\right)$. In other words, the manager favors the higher yielding security if its excess return outweighs its higher probability of a downgrade. For certain values of the parameters the manager will reach for yield: first, when the ratings-based penalty $(\Delta)$ is large, reaching-for-yield is less attractive. Second, when the risk of downgrades $\left(p_{2}^{-}\right)$is higher (for the higher yielding security), the reaching behavior becomes weaker.

We have abstracted from the risk aversion of the manager, and the choice of penalties by the principal. It is also outside of the scope why some principals use penalties as we model them here (e.g., regulatory capital requirements), while others use absolute quantitative rules (e.g., some mutual funds invest exclusively in investment grade bonds).

The conclusion that higher downgrade probabilities weaken the incentive to reach for yield has a straightforward, testable prediction: any bond that faces a higher downgrade probability is less attractive for a manager reaching-for-yield. For insurance companies, both the cost of a downgrade and the probability of a downgrade are increasing in measurable risk (NAIC categories). As discussed earlier, 
capital requirements are convex in NAIC risk categories. In addition, as illustrated in Figure A.1, Panel A the probability of a downgrade is also convex in NAIC risk category. Probability of NAIC 2 asset in the highest CDS quartile to be downgraded is 9\%. However, probability of NAIC 3 asset in the highest CDS quartile to be downgraded is $12 \%$. For the lowest CDS quartile, the corresponding probabilities are only $0 \%$ and $1 \%$. To avoid raising capital, insurance companies could sell its bonds when it is downgraded, but such a strategy has a non-trivial economic cost (e.g., Ellul, Jotikasthria and Lundblad, 2011; Bao, Pan, and Wang, 2011). There is also an additional source of convexity given that highly rated bonds are cheaper to trade than low-rated bonds. Edwards, Harris and Piwowar (2007) point out that, while the difference between investment grade bonds is negligible, high-yield bonds are almost twice as costly to trade as investment grade bonds. What this amounts to is that reaching-for-yield-loading on high CDS within rating category—should be less likely in NAIC categories that correspond to speculative grade ratings.

Our sample covers the financial crisis, and we need to consider carefully how that may affect the propensity to reach for yield. There are at least two reasons why reaching-for-yield should be less likely in the crisis. First, downgrades are cyclical, so all bonds face higher downgrade probabilities. As explained above, this should reduce reaching. Second, it may well be that in a period of high risk and high risk premia such as the crisis, other reasons to avoid risk dominate regulatory constraints. For example, investors may become sufficiently risk averse that they no longer consider capital regulation binding. Kashyap and Stein (2004) develop this argument in the context of bank capital. 
Figure A.1

NAIC Quarterly Transition Probability by CDS Quartile

This figure shows probability of downward (Panel A) and upgrade (Panel B) transition between different NAIC risk categories sorted by CDS quartiles. For example, probability of NAIC 2 asset in the highest CDS quartile to be downgraded is $9 \%$. However, probability of NAIC 3 asset in the highest CDS quartile to be downgraded is $12 \%$. We define downgrade as a change in rating that moves an issuer from one NAIC to any lower NAIC within the quarter of issuance.

\section{A. Downgrades}

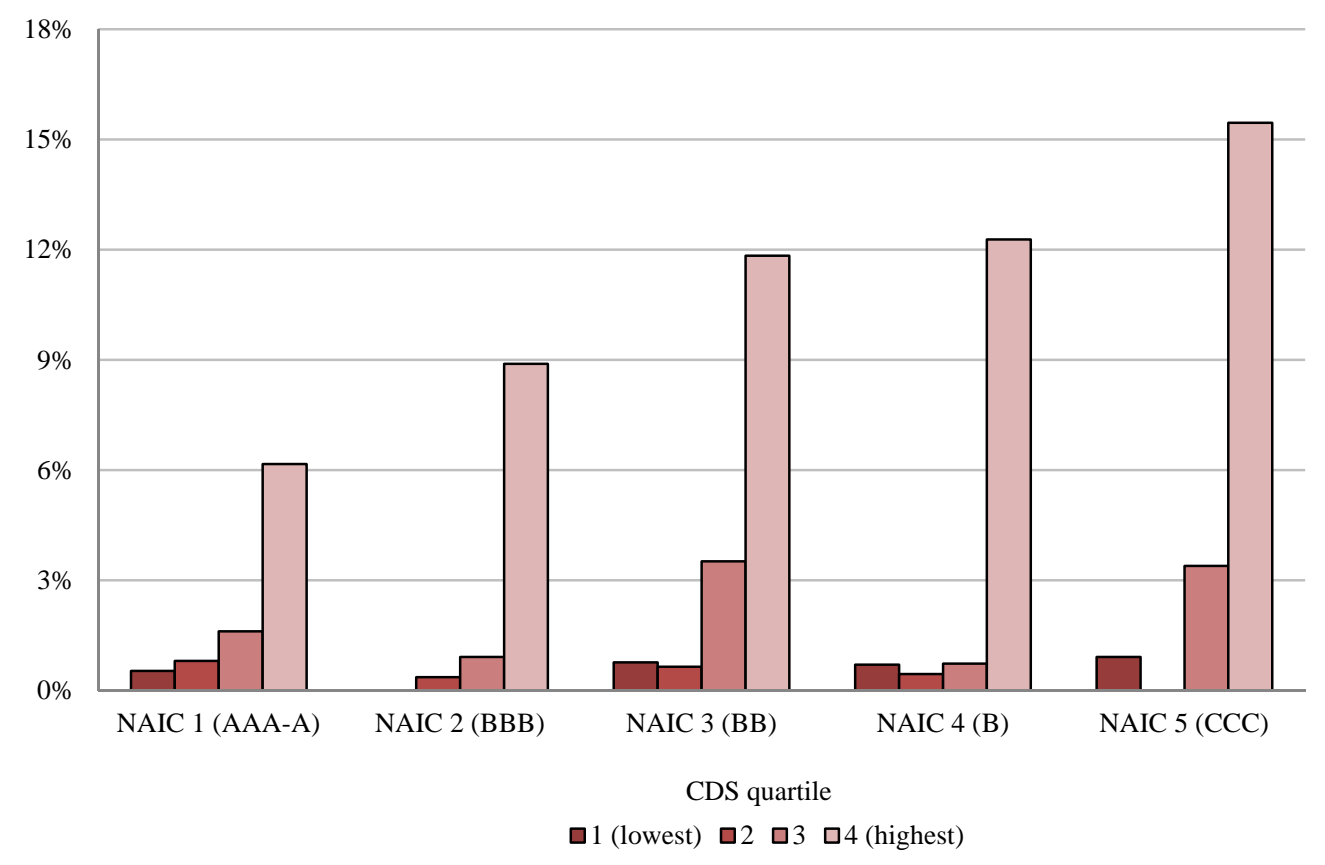

B. Upgrades

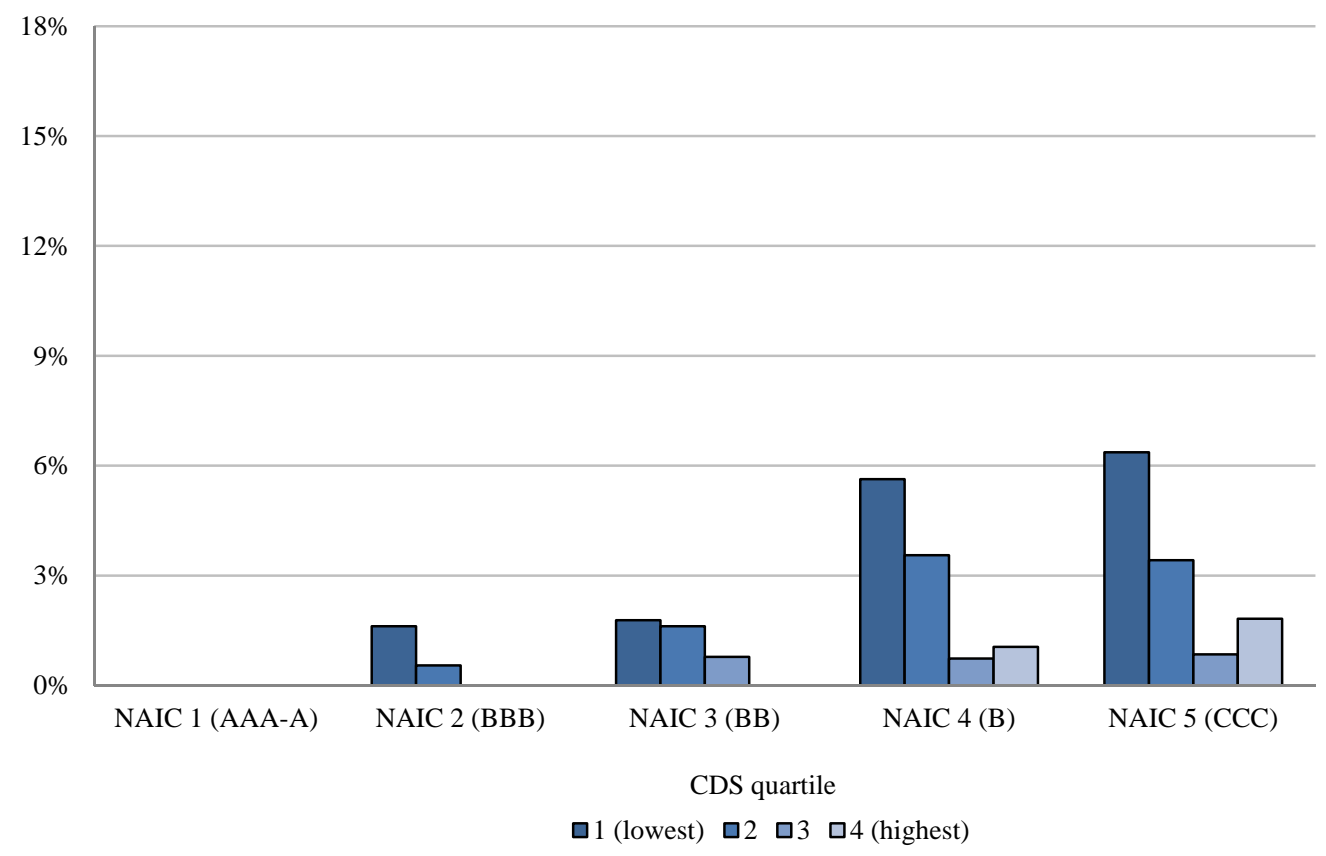

